\title{
Utility of Ankyrin 3 as a Prognostic Marker in Androgen-Receptor-Positive Breast
}

\section{Cancer}

Sasagu Kurozumi ${ }^{1,2}$, Chitra Joseph ${ }^{1}$, Sara Raafat ${ }^{1,3}$, Sultan Sonbul1 ${ }^{1}$, Yousif Kariri1 ${ }^{1}$, Sami Alsaeed $^{1}$, Marian Pigera ${ }^{1}$, Mansour Alsaleem ${ }^{1}$, Christopher C Nolan ${ }^{1}$, Simon Johnston ${ }^{1}$, Mohammed A Aleskandarany ${ }^{1,4}$, Angela Ogden ${ }^{1}$, Takaaki Fujii ${ }^{2}$, Ken Shirabe², Stewart Martin $^{1}$, Ibraheem Alshankyty ${ }^{5}$, Nigel P Mongan ${ }^{6,7}$, Ian O Ellis ${ }^{1}$, Andrew R Green ${ }^{1}$ and Emad A Rakha1,4

1Nottingham Breast Cancer Research Centre, Division of Cancer and Stem Cells, School of Medicine, University of Nottingham, Nottingham, UK

${ }^{2}$ Department of General Surgical Science, Gunma University Graduate School of Medicine, Gunma, Japan

3Department of Pathology, Faculty of Medicine, Mansoura University, Mansoura, Egypt ${ }^{4}$ Faculty of Medicine, Menoufyia University, Shebin El Kom, Egypt

5Faculty of Applied Medical Sciences, King Abdulaziz University, KSA

${ }^{6}$ Cancer Biology and Translational Research, Faculty of Medicine and Health Sciences, University of Nottingham, Nottingham, UK

${ }^{7}$ Department of Pharmacology, Weill Cornell Medicine, New York, USA

\section{Corresponding Author}

Professor Emad Rakha

Department of Histopathology, Division of Cancer and Stem Cells, School of Medicine, The University of Nottingham and Nottingham University Hospitals NHS Trust, Nottingham City Hospital, Nottingham, NG5 1PB, UK

Email: emad.rakha@,nottingham.ac.uk

Running Title: Prognostic Value of ANK3 in AR-Positive Breast Cancer 


\section{Abstract}

Purpose. Androgen receptor (AR) and AR signaling pathways are thought to play a role in breast cancer $(\mathrm{BC})$ and are potentially related to treatment responses and outcomes. Ankyrin 3 (ANK3) is associated with AR stability in cancer cells. In the present study, we investigated the clinicopathological utility of ANK3 expression with emphasis on AR and its associated signalling pathway at transcriptomic and proteomic phases.

Patients and Methods. The Molecular Taxonomy of Breast Cancer International Consortium (METABRIC) cohort $(n=1,980)$ and The Cancer Genome Atlas (TCGA) dataset $(n=1,039)$ were used to assess the expression and significance of $A N K 3$ mRNA and other AR signalling pathway-associated gene signature. Using immunohistochemistry, ANK3 protein expression was evaluated in large $(n=982)$ cohort of early-stage BC with long-term follow-up and compared with clinicopathological characteristics and its prognostic value in the whole cohort and the subgroups stratified by AR protein expression.

Results. An AR-related gene signature was developed, comprising 20 genes, which included $A N K 3$. This AR-related gene signature was significantly associated with $A R$ mRNA expression, oestrogen receptor, human epidermal growth factor receptor 2 (HER2) status and the patients' outcomes. In tumours with high AR protein expression $(n=614)$, high ANK3 protein expression was significantly associated with progesterone receptor positivity and it was independently associated with the good outcomes $(p=0.025)$.

Conclusions. This study indicates that ANK3 is related AR signalling pathway and is associated with BC prognosis.

Keywords: invasive breast cancer, androgen receptor, ankyrin 3, prognostic marker. 


\section{BACKGROUND}

Treatments of breast cancer $(\mathrm{BC})$ are generally determined on the basis of the molecular phenotype of the primary tumour $[1,2]$. However, the biological heterogeneity of $\mathrm{BC}$ constitutes an important determinant of treatment sensitivity, success and outcomes. Hormone-dependent pathways, including androgen receptor (AR) signalling pathways, are thought to play an important role in $\mathrm{BC}$ cell proliferation [3, 4]. Previous studies have indicated that $\mathrm{AR}$ and $\mathrm{AR}$ signaling pathways are associated with treatment resistance and prognosis of $\mathrm{BC}[5,6]$. In previous research, we found that approximately $55 \%$ of $\mathrm{BC}$ had high AR expression, which was observed in $42 \%$ of human epidermal growth factor receptor 2 (HER2)-positive tumours and in $20 \%$ of triple negative BC (TNBC) [7]. Some studies indicate that high AR expression is a good prognostic factor in BC [7, 8]. However, in HER2positive and TNBC subtypes, AR signalling pathways are considered to play an important role in tumour progression. He et al. suggested that AR promotes the growth of HER2positive $\mathrm{BC}$ via crosstalk with the intracellular HER2 downstream pathway [9]. The luminalAR BC subtype, a molecular subtype of TNBC, not only expresses AR but also has enriched hormone-dependent pathways, as demonstrated at the global transcriptomic level $[10,11]$. It has also been shown in oestrogen receptor (ER)-positive and HER2-negative BC that aberrant AR-related oncogenic pathway activation is associated with resistance to endocrine therapy [12].

Ankyrin 3 (ANK3), a member of the ankyrin family of membrane-associated proteins, is believed to link integral membrane proteins to cytoskeletal components. Ankyrins are 
associated with cytoplasmic structures and are also necessary in the regulation of cell migration and adhesion and for the maintenance of cellular membrane domains [13-15]. ANK3 has been suggested to play a role in regulating the stability and turnover of AR and is closely associated with AR genomic activities [16]. AR signaling pathway promotes cancer cell proliferation by increasing cyclin-dependent kinase activity $[17,18]$ and ANK3 regulates the expression of cell cycle components as cyclins A and B [16]. Hence, ANK3 may play an important role in AR signaling pathway in cancer. However, the association between ANK3 expression and AR signaling pathway in $\mathrm{BC}$ remains poorly defined. In this study, $A N K 3$ was first evaluated as a component of the AR signaling pathway in $\mathrm{BC}$, utilising well characterised large cohort transcriptomic databases. The clinicopathological and prognostic significance of ANK3 protein expression levels was assessed using immunohistochemistry (IHC) in a large series of BC patients' specimens.

\section{MATERIALS AND METHODS}

\section{Cluster Analysis of AR-Signaling-Pathway-Associated Genes}

Gene Ontology (GO) Consortium is the large genomic annotation project and widely used as biological databases for annotating genes to the previous evidence regarding their biological role $[19,20]$. GO terms are divided into 3 categories as biological process, molecular function and cellular component [21]. In GO terms of the biological process, gene symbols related to 'Regulation Of Androgen Receptor Signaling Pathway (GO: 0060765)' were accessed using the online database Gene Set Enrichment Analysis (http:// softwa re.broadinstitute.org/g s e / m sigd b/cards/ GO_REGULATION_OF_ANDROGEN_RECEPTOR_SIGNALING_PATHWAY) [22, 23]. 
The mRNA expression data of these genes, including $A N K 3$, together with the clinicopathological characteristics and outcomes of patients with $\mathrm{BC}$, were collected from the Molecular Taxonomy of Breast Cancer International Consortium (METABRIC) dataset [24, 25] $(n=1,980)$ and the Cancer Genome Atlas (TCGA) [26] dataset $(n=1,039)$ provided by cBioPortal [27].

The normalisation method of mRNA expression in the METABRIC cohort was previously described [24]. TCGA mRNA data was $\log _{2}$-transformed prior to cluster analysis. For cluster analysis [28] and heat mapping construction, Cluster 3.0 and Java Treeview was used [29]. Data were filtered to remove all genes that did not have at least one observation with absolute values greater than 2.0 or whose maximum minus minimum values were less than 2.0 .

\section{ANK3 Protein Expression}

A total of $982 \mathrm{BC}$ patients who underwent surgery at Nottingham City Hospital in the UK between 1987 and 1998 (referred to as the Nottingham Primary Breast Cancer Series) were included in this study. All patients had undergone breast-conserving surgery or modified radical mastectomy without any neoadjuvant treatment. The availability and assessment of hormone receptors (AR, ER and progesterone receptor [PR]), HER2 and Ki67 were described in previous studies [7, 30-37]. The cohort was stratified on the basis of AR expression [7], with 614 patients $(62.5 \%)$ with high and 368 patients $(37.5 \%)$ with low AR expression (Supplementary Table 1).

ANK3 protein expression was assessed by IHC using an anti-ANK3 antibody (HPA055643; Merck, Darmstadt, Germany) diluted 1:300 as previously described [38-40]. In order to evaluate the pattern of ANK3 protein expression, 15 full-face $\mathrm{BC}$ tissue sections were 
assessed prior to staining the whole cohort $(n=982)$ prepared as tissue microarrays (TMAs). Immunostained TMA sections were digitally scanned using a NanoZoomer (Hamamatsu Photonics, Tokyo, Japan). Cytoplasmic staining of ANK3 in cancer cells was assessed using the $\mathrm{H}$-score method on the basis of intensity scoring $(0=$ negative, $1=$ weak, $2=$ moderate, 3 $=$ strong $)$ and proportion scoring $(0-100)$ as previously reported [41, 42].

\section{Statistical Analysis}

Statistical analyses were conducted using SPSS v24.0 (IBM, Armonk, NY, USA). The relationship between $A N K 3$ mRNA with ANK3 protein expression and $A R$ mRNA expression was examined using Pearson's correlation coefficient test. In order to assess the associations between $A R$ mRNA expression and groups stratified by the AR-related gene signature, the Mann-Whitney $U$ test was used. The chi-square test as univariate analysis and the logistic regression test as multivariate analysis were used to assess several clinicopathological factors, including tumour size, lymph node status, histological grade, ER, PR, HER2 and molecular subtypes, stratified by groups based on AR-related gene signature and levels of ANK3 protein expression. In order to assess the prognostic utility of ANK3 expression, Kaplan-Meier survival curves was used. In univariate and multivariate analyses, to assess the associations between clinicopathological factors, including ANK3 expression, and prognosis, 95\% confidence intervals (CIs) were assessed using the Cox proportional hazards regression model. In these survival analyses, the median value $(\mathrm{H}$-score $=120)$ was used as a cut-off point to divide the samples into high and low expression groups.

\section{RESULTS}




\section{ANK3 mRNA Expression and AR Signaling Pathway Gene Signature}

High $A N K 3$ mRNA expression was significantly associated with high $A R$ mRNA expression (METABRIC: $r=0.019, p=0.39$; TCGA: $r=0.28, p<0.0001$ ) in TCGA cohort. An ARrelated gene signature was developed using genomic data filtering, and this comprised 20 genes, including $A N K 3$ and 19 other relevant genes available in the databases: $A R R B 2$, BUD31, DAB2, DDX5, EP300, FOXP1, HDAC1, HDAC6, HEYL, PARK7, PHB, PIAS2, PRMT2, RNF14, RNF6, SFRP1, SIRT1, SMARCA4 and TRIM68 (Supplementary Table 2). Using the dendrogram of cluster analysis, the METABRIC and TCGA cohorts were stratified into two groups on the basis of the AR-signaling-pathway-associated genes [Figs. 1(a) and 1(b)], where tumours in group 1 had significantly lower $A R$ mRNA expression than that in Group 2 ( $p<0.0001)$. Group 1 tumours included 899 (45\%) from the METABRIC and 541 $(52 \%)$ from TCGA cohort.

In the METABRIC and TCGA cohorts, multivariate analysis indicated that the AR-related gene signature in group 2 was significantly associated with lower grade $(p=0.0070$, and $p=$ 0.0093 respectively), ER positivity ( $p<0.0001$, and $p<0.0001$ respectively), and HER2 positivity $(p<0.0001$ and $p<0.0001$; Table 1$)$. In the METABRIC cohort, the AR-related gene signature was significantly associated with molecular subtype $(p<0.0001)$, with $83 \%$ of the basal-like tumours in group 1 and $90 \%$ of the luminal B tumours in group 2 (Table 1). Although the expression of $A N K 3$ and $A R$ mRNA was not a significant independent prognostic factor in BC (Supplementary Figure 1), there was an association between ARrelated gene signature subgroups and patients' outcomes, where patients with the AR-related gene signature group 2 showed significantly worse outcome than those with Group 1 tumours

[METABRIC: hazard ratio (HR) 1.25, 95\% CI: 1.09-1.43, $p=0.0013$; TCGA: HR 1.61, 95\% 
CI: 1.11-2.32, $p=0.011$; Figs. 1(c) and 1(d)]. On multivariate analysis, AR-related gene signature group 2 was an independent prognostic factor predicting poor outcomes in both cohorts (METABRIC: HR 1.23, 95\% CI: 1.06-1.42, $p=0.0066$; TCGA: HR 1.82, 95\% CI: 1.08-3.06, $p=0.026$; Table 2).

\section{Immunohistochemical Expression of ANK3 Protein}

The assessment of ANK3 in full-face tissue sections indicated that the pattern of ANK3 expression in cancer cells was homogeneous, but it differed from that in normal mammary glands [Figs. 2(a)-2(c)]. ANK3 expression was observed in the normal glandular and luminal epithelial cells, where it was stronger than the surrounding myoepithelial cells. ANK3 immunopositivity was observed in the cytoplasm of invasive cancer cells and was typically weaker than in the adjacent normal epithelial cells [Figs. 2(c)-2(e)].

In 198 cases in the METABRIC dataset, which overlapped with the Nottingham Primary Series, $A N K 3$ mRNA and ANK3 protein expression were significantly correlated $(r=0.15, p$ $=0.039)$. In the Nottingham series, 579 (59\%) tumours had low ANK3 expression (H-score $\leq$ 120) and 403 (41\%) had high ANK3 expression (H-score > 120). High AR expression was present in $614(63 \%)$ tumours and low AR expression was present in 368 (37\%). Among those with high AR expression, 250 (41\%) also had high ANK3 expression. A similar proportion $(153,42 \%)$ had high ANK3 expression in the low AR expression group $(n=368)$. AR expression was not associated with ANK3 expression on proteomic analysis $(p=0.79)$. When all 982 cases were combined (i.e. not stratified according to AR expression), ANK3 was not a significant prognostic factor (Supplementary Figure 2). 
In tumours with high AR expression, high ANK3 expression was significantly associated with PR positivity ( $p=0.014$; Supplementary Table 3). In terms of BC-specific survival, high AR protein expression was a significant good prognostic factor (HR 0.66, 95\% CI: 0.52-0.84, $p=0.00066$; Supplementary Figure 3). Low ANK3 protein expression was a poor prognostic factor in patients with high AR expression [HR 1.49, 95\% CI: 1.07-2.09, $p=0.020$; Figs. 3(a)-3(e)], but not in those whose tumours had low AR expression (HR 0.89, 95\% CI: 0.62-1.28, $p=0.53$; Supplementary Figure 4). In high-AR-expressing BC patients, univariate analysis using the Cox proportional hazards regression analysis identified low ANK3 expression, large tumour size (HR 2.61, $p<0.0001$ ), positive nodal status (HR 2.84, $p<$ $0.0001)$ and high histological grade (HR 3.27, $p<0.0001$ ) as poor prognostic factors. On multivariate analysis, low ANK3 protein expression was an independent prognostic factor predicting poor outcomes in $\mathrm{BC}$ with high $\mathrm{AR}$ expression (HR 1.47, $p=0.025$; Table 3 ).

\section{DISCUSSION}

$\mathrm{AR}$ expression is a crucial factor in the progression of $\mathrm{BC}$, as it controls the expression of various genes and proteins through a genomic pathway $[5,6]$. In this pathway, AR mediates intracellular steroid hormone-related signaling pathways to regulate the transcription of target genes in conjunction with other transcription factors, such as signal transducers and activators of transcription $[43,44]$. As a mechanism involved in the development of BC, AR expression might be involved in the crosstalk with epidermal growth factor receptor pathways, such as human epidermal growth factor receptor 1 (EGFR) and HER2 signaling [45]. In this study, there were a significant correlation between $A N K 3$ and $A R$ mRNA and $A N K 3$ was one of the gene component of the AR-related gene signature. When $\mathrm{BC}$ was classified into 2 groups 
based on the expression of AR-related gene signature, the group 2 gene signature, which was associated with high $A R$ mRNA expression and present in $90 \%$ of luminal B tumours, was a significant prognostic factor indicating poor outcomes in BC. This finding suggests that aberrant AR-related oncogenic pathway activation is associated with a number of factors that portend a poor BC outcome.

In a previous study using microarray gene expression analysis, the downregulation of $A N K 3$ was included in an 11-gene signature associated with poor prognosis in patients with various cancers including $\mathrm{BC}$ [46]. In a meta-analysis of gene expression signatures in $\mathrm{BC}$, the downregulation of $A N K 3$ appeared to enhance cancer cell differentiation, proliferation and metastasis [47]. Previous research using microarray data of prostate cancer suggested that low ANK3 expression is related to positivity for ERG, member of the erythroblast transformation-specific family [48]. ERG is correlated with AR activity [49], transcriptional stability [50] and stem cell maintenance [51] in multiple cancers. Prostate cancer cells with ANK3 knockdown exhibit significant increases in cell invasion through an AR-dependent mechanism as a regulator of AR protein stability [16]. In the present study, the association between ANK3 protein expression and outcomes was highly significant in BC with high AR expression. In addition, high ANK3 protein expression was associated with PR positivity. These findings suggest that ANK3 may play an important role in the maintenance of hormonal activity, and AR stabilisation by ANK3 may therefore be related to the improved outcomes in $\mathrm{BC}$ patients with high $\mathrm{AR}$ expression. A proportion of ER-negative $\mathrm{BC}$ are generally considered to retain active AR signaling [6, 52]. Several prospective clinical trials of AR-targeted therapies have been conducted on TNBC with high AR expression. These trials indicated that treatment with an AR inhibitor is feasible, with a clinical benefit rate of 
approximately $20 \%$ in TNBC [53-55]. The upregulation of ANK3 may increase AR stability and improve the response to an AR inhibitor in TNBC. Further functional and translational research is necessary in order to explore the association of ANK3 with AR stability with the efficacy of treating BC with an AR inhibitor.

In conclusion, the AR signaling pathway and $A N K 3$ mRNA expression are associated with $A R$ mRNA expression and BC prognosis. High ANK3 protein expression is an independent prognostic factor in $\mathrm{BC}$ with high $\mathrm{AR}$ expression. Overall, these findings indicate that ANK3 may play an important role in breast tumour progression and, in conjunction with AR, may be related to $\mathrm{BC}$ outcomes.

\section{Acknowledgements}

We thank the Nottingham Health Science Biobank and Breast Cancer Now Tissue Bank for the provision of tissue samples.

\section{Compliance with Ethical Standards}

\section{Funding}

This study was funded by the University of Nottingham (Nottingham Life Cycle 6).

\section{$\underline{\text { Conflict of Interest }}$}

Ibraheem Alshankyty is a consultant/advisory board in Molecular Diagnostics Lab, College of Applied Med. Sci., KAU.

All authors of this work declare that they have no conflict of interest. 


\section{Ethical approval}

This study was approved by the Nottingham Research Ethics Committee 2 (Reference title:

Development of a molecular genetic classification of breast cancer). All procedures performed in studies involving human participants were in accordance with the ethical standards of the institutional and/or national research committee and with the 1964 Helsinki declaration and its later amendments or comparable ethical standards.

\section{$\underline{\text { Informed consent }}$}

Informed consent was obtained from the participants included in the study.

\section{References}

1. Coates AS, Winer EP, Goldhirsch A, Gelber RD, Gnant M, Piccart-Gebhart M, Thürlimann B, Senn HJ; Panel Members (2015) Tailoring therapies-improving the management of early breast cancer: St Gallen International Expert Consensus on the Primary Therapy of Early Breast Cancer 2015. Ann Oncol 26:1533-1546.

2. Curigliano G, Burstein HJ, P Winer E, Gnant M, Dubsky P, Loibl S, Colleoni M, Regan MM, Piccart-Gebhart M, Senn HJ, Thürlimann B; St. Gallen International expert consensus on the primary therapy of early breast cancer 2017 (2017) De-escalating and escalating treatments for early-stage breast cancer: the St. Gallen International Expert Consensus Conference on the primary therapy of early breast cancer 2017. Ann Oncol 28:1700-1712.

3. Kurozumi S, Matsumoto H, Hayashi Y, Tozuka K, Inoue K, Horiguchi J, Takeyoshi I, Oyama T, Kurosumi M (2017) Power of PgR expression as a prognostic factor for ER- 
positive/HER2-negative breast cancer patients at intermediate risk classified by the Ki67 labelling index. BMC Cancer 17:354.

4. Hayashi S, Yamaguchi Y 2008 Estrogen signalling pathway and hormonal therapy. Breast Cancer 15:256-261.

5. Iacopetta D, Rechoum Y, Fuqua SA (2012) The role of androgen receptor in breast cancer. Drug Discov Today Dis Mech 9:e19-e27.

6. Rampurwala M, Wisinski KB, O'Regan R (2016) Role of the androgen receptor in triplenegative breast cancer. Clin Adv Hematol Oncol 14:186-93.

7. Aleskandarany MA, Abduljabbar R, Ashankyty I, Elmouna A, Jerjees D, Ali S, Buluwela L, Diez-Rodriguez M, Caldas C, Green AR, Ellis IO, Rakha EA (2016) Prognostic significance of androgen receptor expression in invasive breast cancer: transcriptomic and protein expression analysis. Breast Cancer Res Treat 159:215-227.

8. Vera-Badillo FE, Templeton AJ, de Gouveia P, Diaz-Padilla I, Bedard PL, Al-Mubarak M, Seruga B, Tannock IF, Ocana A, Amir E (2014) Androgen receptor expression and outcomes in early breast cancer: a systematic review and meta-analysis. J Natl Cancer Inst 106:djt319.

9. He L, Du Z, Xiong X, Ma H, Zhu Z, Gao H, Cao J, Li T, Li H, Yang K, Chen G, Richer JK, Gu H (2017) Targeting androgen receptor in treating HER2 positive breast cancer. Sci Rep 7:14584.

10. Lehmann BD, Bauer JA, Chen X, Sanders ME, Chakravarthy AB, Shyr Y, Pietenpol JA (2011) Identification of human triple-negative breast cancer subtypes and preclinical models for selection of targeted therapies. J Clin Invest 121:2750-2767.

11. Masuda H, Baggerly KA, Wang Y, Zhang Y, Gonzalez-Angulo AM, Meric-Bernstam F, Valero V, Lehmann BD, Pietenpol JA, Hortobagyi GN, Symmans WF, Ueno NT (2013) 
Differential response to neoadjuvant chemotherapy among 7 triple-negative breast cancer molecular subtypes. Clin Cancer Res 19:5533-5540.

12. Fujii R, Hanamura T, Suzuki T, Gohno T, Shibahara Y, Niwa T, Yamaguchi Y, Ohnuki K, Kakugawa Y, Hirakawa H, Ishida T, Sasano H, Ohuchi N, Hayashi S (2014) Increased androgen receptor activity and cell proliferation in aromatase inhibitor-resistant breast carcinoma. J Steroid Biochem Mol Biol 144:513-522.

13. Lambert S, Bennett V (1993) From anemia to cerebellar dysfunction. A review of the ankyrin gene family. Eur J Biochem 211:1-6.

14. Bennett V (1992) Ankyrins. Adaptors between diverse plasma membrane proteins and the cytoplasm. J Biol Chem 267:8703-8706.

15. De Matteis MA, Morrow JS (1998) The role of ankyrin and spectrin in membrane transport and domain formation. Curr Opin Cell Biol 10:542-549.

16. Wang T, Abou-Ouf H, Hegazy SA, Alshalalfa M, Stoletov K, Lewis J, Donnelly B, Bismar TA (2016) Ankyrin G expression is associated with androgen receptor stability, invasiveness, and lethal outcome in prostate cancer patients. J Mol Med (Berl) 94:1411-1422.

17. Ramos-Montoya A, Lamb AD, Russell R, Carroll T, Jurmeister S, Galeano-Dalmau N, Massie CE, Boren J, Bon H, Theodorou V, Vias M, Shaw GL, Sharma NL, Ross-Adams H, Scott HE, Vowler SL, Howat WJ, Warren AY, Wooster RF, Mills IG, Neal DE (2014) HES6 drives a critical AR transcriptional programme to induce castration-resistant prostate cancer through activation of an E2F1-mediated cell cycle network. EMBO Mol Med 6:651-661.

18. Pietri E, Conteduca V, Andreis D, Massa I, Melegari E, Sarti S, Cecconetto L, Schirone A, Bravaccini S, Serra P, Fedeli A, Maltoni R, Amadori D, De Giorgi U, Rocca A (2016) 
Androgen receptor signaling pathways as a target for breast cancer treatment. Endocr Relat Cancer 23:R485-98.

19. Ashburner M, Ball CA, Blake JA, Botstein D, Butler H, Cherry JM, Davis AP, Dolinski K, Dwight SS, Eppig JT, Harris MA, Hill DP, Issel-Tarver L, Kasarskis A, Lewis S, Matese JC, Richardson JE, Ringwald M, Rubin GM, Sherlock G.B (2000) Gene ontology: tool for the unification of biology. The Gene Ontology Consortium. Nat Genet 25:25-29.

20. The Gene Ontology Consortium (2017) Expansion of the Gene Ontology knowledgebase and resources. Nucleic Acids Res 45:D331-D338.

21. Rhee SY, Wood V, Dolinski K, Draghici S (2008) Use and misuse of the gene ontology annotations. Nat Rev Genet 9:509-515.

22. Subramanian A, Tamayo P, Mootha VK, Mukherjee S, Ebert BL, Gillette MA, Paulovich A, Pomeroy SL, Golub TR, Lander ES, Mesirov JP (2005) Gene set enrichment analysis: a knowledge-based approach for interpreting genome-wide expression profiles. Proc Natl Acad Sci U S A 102:15545-15550.

23. Mootha VK, Lindgren CM, Eriksson KF, Subramanian A, Sihag S, Lehar J, Puigserver P, Carlsson E, Ridderstråle M, Laurila E, Houstis N, Daly MJ, Patterson N, Mesirov JP, Golub TR, Tamayo P, Spiegelman B, Lander ES, Hirschhorn JN, Altshuler D, Groop LC (2003) PGC-1alpha-responsive genes involved in oxidative phosphorylation are coordinately downregulated in human diabetes. Nat Genet 34:267-273.

24. Curtis C, Shah SP, Chin SF, Turashvili G, Rueda OM, Dunning MJ, Speed D, Lynch AG, Samarajiwa S, Yuan Y, Gräf S (2012) The genomic and transcriptomic architecture of 2,000 breast tumours reveals novel subgroups. Nature 486:346-352. 
25. Pereira B, Chin SF, Rueda OM, Vollan HK, Provenzano E, Bardwell HA Pugh M, Jones L, Russell R, Sammut SJ, Tsui DW (2016) The somatic mutation profiles of 2,433 breast cancers refines their genomic and transcriptomic landscapes. Nat Commun 10:11479.

26. Cancer Genome Atlas Network (2012) Comprehensive molecular portraits of human breast tumours. Nature 490:61-70.

27. Cerami E, Gao J, Dogrusoz U, Gross BE, Sumer SO, Aksoy BA, Jacobsen A, Byrne CJ, Heuer ML, Larsson E, Antipin Y (2012) The cBio cancer genomics portal: an open platform for exploring multidimensional cancer genomics data. Cancer Discov 2:401-404.

28. Eisen MB, Spellman PT, Brown PO, Botstein D (1998) Cluster analysis and display of genome-wide expression patterns. Proc Natl Acad Sci USA 95:14863-14868.

29. De Hoon MJL, Imoto S, Nolan J, Miyano S. (2004) Open source clustering software. Bioinformatics 20:1453-1454.

30. Rakha EA, Agarwal D, Green AR, Ashankyty I, Ellis IO, Ball G, Alaskandarany MA (2017) Prognostic stratification of oestrogen receptor-positive HER2-negative lymph node-negative class of breast cancer. Histopathology 70:622-631.

31. Rakha EA, Elsheikh SE, Aleskandarany MA, Habashi HO, Green AR, Powe DG, ElSayed ME, Benhasouna A, Brunet JS, Akslen LA, Evans AJ (2009) Triple-negative breast cancer: distinguishing between basal and nonbasal subtypes. Clin Cancer Res $15: 2302-2310$.

32. Green AR, Powe DG, Rakha EA, Soria D, Lemetre C, Nolan CC, Barros FF, Macmillan RD, Garibaldi JM, Ball GR, Ellis IO (2013) Identification of key clinical phenotypes of breast cancer using a reduced panel of protein biomarkers. Br J Cancer 109:1886-1894. 
33. Rakha EA, Soria D, Green AR, Lemetre C, Powe DG, Nolan CC, Garibaldi JM, Ball G, Ellis IO (2014) Nottingham Prognostic Index Plus (NPI+): a modern clinical decision making tool in breast cancer. Br J Cancer 110:1688-1697.

34. Habashy HO, Powe DG, Rakha EA, Ball G, Paish C, Gee J, Nicholson RI, Ellis IO (2008) Forkhead-box A1 (FOXA1) expression in breast cancer and its prognostic significance. Eur J Cancer 44:1541-1551.

35. Habashy HO, Powe DG, Glaab E, Ball G, Spiteri I, Krasnogor N, Garibaldi JM, Rakha EA, Green AR, Caldas C, Ellis IO (2011) RERG (Ras-like, oestrogen-regulated, growthinhibitor) expression in breast cancer: a marker of ER-positive luminal-like subtype. Breast Cancer Res Treat 128:315-326.

36. Aleskandarany MA, Rakha EA, Ahmed MA, Powe DG, Ellis IO, Green AR (2011) Clinicopathologic and molecular significance of phosphor-Akt expression in early invasive breast cancer. Breast Cancer Res Treat 127:407-416.

37. Aleskandarany MA, Rakha EA, Ahmed MA, Powe DG, Paish EC, Macmillan RD, Ellis IO, Green AR (2010) PIK3CA expression in invasive breast cancer: a biomarker of poor prognosis. Breast Cancer Res Treat 122:45-53.

38. Joseph C, Macnamara O, Craze M, Russell R, Provenzano E, Nolan CC Diez-Rodriguez M, Sonbul SN, Aleskandarany MA, Green AR, Rakha EA (2018) Mediator complex (MED) 7: a biomarker associated with good prognosis in invasive breast cancer, especially ER+ luminal subtypes. Br J Cancer 118:1142-1151.

39. Kurozumi S, Joseph C, Sonbul S, Aleskandarany MA, Pigera M, Alsaleem M, Alsaeed S, Kariri Y, Nolan CC, Diez-Rodriguez M, Johnston S, Mongan NP, Fujii T, Shirabe K, Martin SG, Ellis IO, Green AR, Rakha EA (2018) Clinicopathological and prognostic 
significance of Ras association and pleckstrin homology domains 1 (RAPH1) in breast cancer. Breast Cancer Res Treat. https://doi.org/10.1007/s10549-018-4891-y

40. Kurozumi S, Joseph C, Sonbul S, Gorringe KL, Pigera M, Aleskandarany MA, DiezRodriguez M, Nolan CC, Fujii T, Shirabe K, Kuwano H, Storr S, Martin SG, Ellis IO, Green AR, Rakha EA (2018) Clinical and biological roles of Kelch-like family member 7 in breast cancer: a marker of poor prognosis. Breast Cancer Res Treat 170:525-533.

41. McCarty KS Jr, Miller LS, Cox EB, Konrath J, McCarty KS Sr (1985) Estrogen receptor analyses. Correlation of biochemical and immunohistochemical methods using monoclonal antireceptor antibodies. Arch Pathol Lab Med 109:716-721.

42. Detre S, Saclani Jotti G, Dowsett MA (1995) "Quickscore" method for immunohistochemical semiquantitation: validation for oestrogen receptor in breast carcinomas. J Clin Pathol 48:876-878.

43. Dimitrakakis C, Bondy C (2009) Androgens and the breast. Breast Cancer Res 11:212.

44. Garay JP, Karakas B, Abukhdeir AM, Cosgrove DP, Gustin JP, Higgins MJ, Konishi H, Konishi Y, Lauring J, Mohseni M, Wang GM, Jelovac D, Weeraratna A, Sherman Baust CA, Morin PJ, Toubaji A, Meeker A, De Marzo AM, Lewis G, Subhawong A, Argani P, Park BH (2012) The growth response to androgen receptor signaling in ER $\alpha$-negative human breast cells is dependent on p21 and mediated by MAPK activation. Breast Cancer Res14:R27.

45. Chia KM, Liu J, Francis GD, Naderi A (2011) A feedback loop between androgen receptor and ERK signaling in estrogen receptor-negative breast cancer. Neoplasia13:154-166. 
46. Glinsky GV, Berezovska O, Glinskii AB (2005) Microarray analysis identifies a deathfrom-cancer signature predicting therapy failure in patients with multiple types of cancer. J Clin Invest 115:1503-21.

47. Gröger CJ, Grubinger M, Waldhör T, Vierlinger K, Mikulits W (2012) Meta-analysis of gene expression signatures defining the epithelial to mesenchymal transition during cancer progression. PLoS One 7:e51136.

48. Bismar TA, Alshalalfa M, Petersen LF, Teng LH, Gerke T, Bakkar A, Al-Mami A, Liu S, Dolph M, Mucci LA, Alhajj R (2014) Interrogation of ERG gene rearrangements in prostate cancer identifies a prognostic 10-gene signature with relevant implication to patients' clinical outcome. BJU Int 113:309-319.

49. Yu J, Yu J, Mani RS, Cao Q, Brenner CJ, Cao X, Wang X, Wu L, Li J, Hu M, Gong Y, Cheng H, Laxman B, Vellaichamy A, Shankar S, Li Y, Dhanasekaran SM, Morey R, Barrette T, Lonigro RJ, Tomlins SA, Varambally S, Qin ZS, Chinnaiyan AM (2010) An integrated network of androgen receptor, polycomb, and TMPRSS2-ERG gene fusions in prostate cancer progression. Cancer Cell 17:443-54.

50. Shah AV, Birdsey GM, Randi AM (2016) Regulation of endothelial homeostasis, vascular development and angiogenesis by the transcription factor ERG. Vascul Pharmacol86:3-13.

51. Polson ES, Lewis JL, Celik H, Mann VM, Stower MJ, Simms MS, Rodrigues G, Collins AT, Maitland NJ (2013) Monoallelic expression of TMPRSS2/ERG in prostate cancer stem cells. Nat Commun 4:1623.

52. Vranic S, Feldman R, Gatalica Z (2017) Apocrine carcinoma of the breast: A brief update on the molecular features and targetable biomarkers. Bosn J Basic Med Sci 17: 9-11. 
53. Gucalp A, Tolaney S, Isakoff SJ, Ingle JN, Liu MC, Carey LA, Blackwell K, Rugo H, Nabell L, Forero A, Stearns V, Doane AS, Danso M, Moynahan ME, Momen LF, Gonzalez JM, Akhtar A, Giri DD, Patil S, Feigin KN, Hudis CA, Traina TA (2019) Translational Breast Cancer Research Consortium (TBCRC 011). Phase II trial of bicalutamide in patients with androgen receptor-positive, estrogen receptor-negative metastatic Breast Cancer. Clin Cancer Res 19:5505-12.

54. O'Shaughnessy J, Campone M, Brain E, Neven P, Hayes D, Bondarenko I, Griffin TW, Martin J, De Porre P, Kheoh T, Yu MK, Peng W, Johnston S (2016). Abiraterone acetate, exemestane or the combination in postmenopausal patients with estrogen receptorpositive metastatic breast cancer. Ann Oncol 27: 106-113.

55. Traina TA, Miller K, Yardley DA, Eakle J, Schwartzberg LS, O'Shaughnessy J, Gradishar W, Schmid P, Winer E, Kelly C, Nanda R, Gucalp A, Awada A, Garcia-Estevez L, Trudeau ME, Steinberg J, Uppal H, Tudor IC, Peterson A, Cortes J (2018) Enzalutamide for the Treatment of Androgen Receptor-Expressing Triple-Negative Breast Cancer. J Clin Oncol 36:884-890.

\section{Figures Captions}

Fig. 1. Prognostic utility of an androgen receptor (AR)-related gene signature, including ANK3 mRNA expression.

Heat map of the AR-related gene signature for the (a) METABRIC and (b) TCGA cohorts generated by unsupervised cluster analysis, showing a clear division of cases between Group 1 and Group 2 on the basis of the AR-related gene expression. The overall survival of patients 
with breast cancer with the AR-related Group 2 gene signature was significantly worse than that of those with the Group 1 gene signature in the (c) METABRIC and (d) TCGA cohorts.

Fig. 2. Morphological characteristics of ANK3 immunohistochemistry in breast cancer tissue.

(a) ANK3 immunoreactivity differs between invasive cancer cells and adjacent normal mammary glandular tissues (black arrow: invasive cancer cells; white arrow: normal mammary gland). Immunoreactivity in normal mammary gland cells is stronger than that in invasive cancer cells (magnification: x100). (b) Invasive cancer cells showing uniform ANK3 immunoreactivity primarily in the cytoplasm (magnification: x200). (c) ANK3 immunoreactivity is uniformly strong in normal epithelial cells and weaker in myoepithelial cells than in glandular cells (magnification: $\mathrm{x} 400$ ). Tissue microarray images of breast cancer tissue samples immunohistochemically stained for ANK3, showing (d) no staining, (e) weak staining and (f) strong staining in the cytoplasm of cancer cells (magnification: x200).

Fig. 3. ANK3 protein expression in breast cancer and cumulative survival rates stratified by ANK3 expression. (a-d) ANK3 and AR expression in breast cancer. Case 1: high ANK3 (a) and high AR (b) expression. Case 2: low ANK3 (c) and high AR (d) expression (magnification: x200 for all images). (e) With high AR expression, BC-specific survival was significantly worse in those with low than high ANK3 expression. 
Table 1. Clinicopathological characteristics of breast cancer associated with AR signaling pathway-related gene signature.

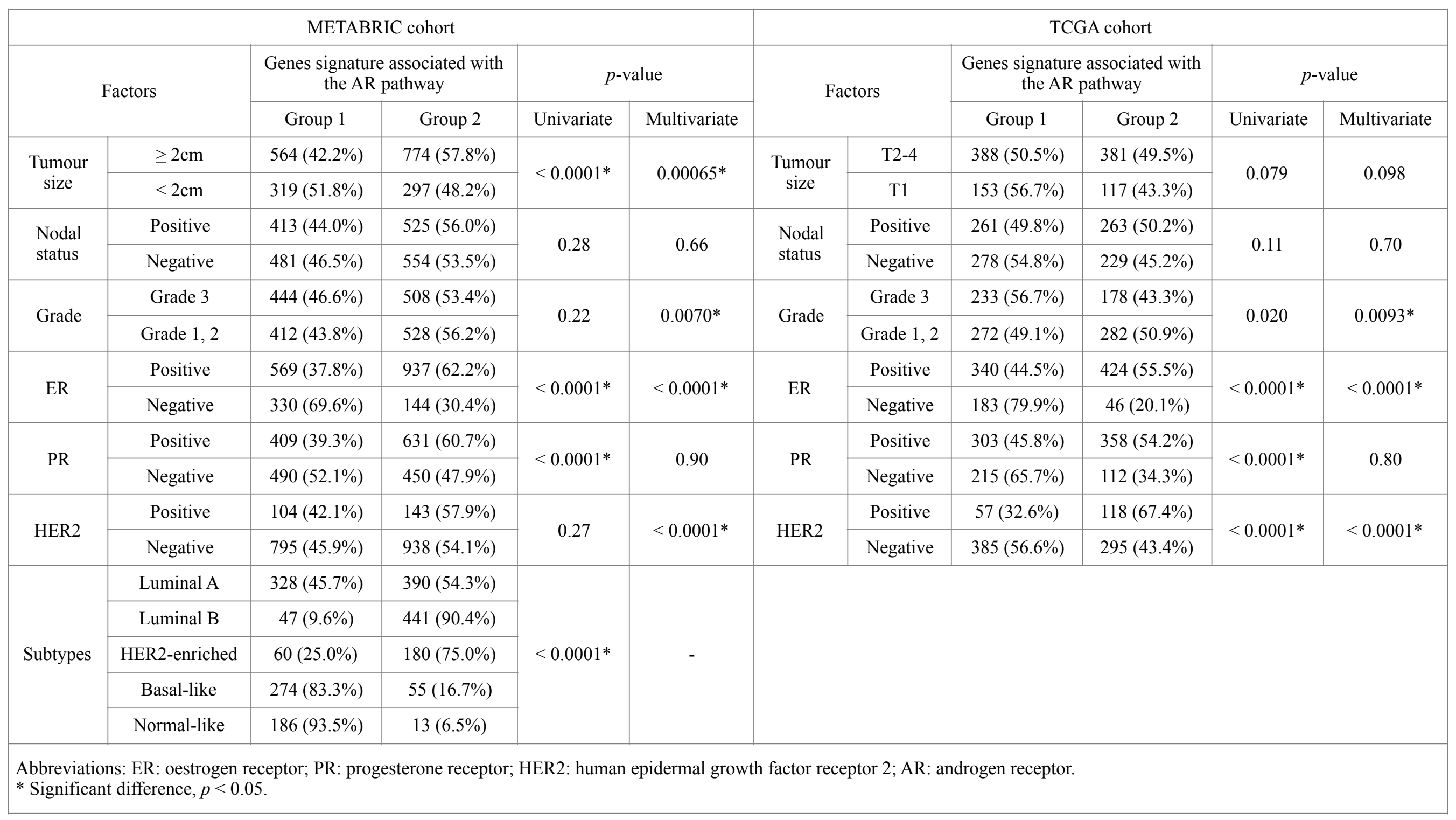


Table 2. Survival analysis based on clinicopathological characteristics of breast cancer, including AR signaling pathway-related gene signature.

\begin{tabular}{|c|c|c|c|c|c|c|c|c|c|c|c|c|c|c|c|}
\hline \multirow{3}{*}{\multicolumn{2}{|c|}{ Factors }} & \multicolumn{6}{|c|}{ METABRIC cohort } & \multirow{3}{*}{\multicolumn{2}{|c|}{ Factors }} & \multicolumn{6}{|c|}{ TCGA cohort } \\
\hline & & \multicolumn{3}{|c|}{ Univariate analysis } & \multicolumn{3}{|c|}{ Multivariate analysis } & & & \multicolumn{3}{|c|}{ Univariate analysis } & \multicolumn{3}{|c|}{ Multivariate analysis } \\
\hline & & $\begin{array}{l}\text { Hazard } \\
\text { Ratio }\end{array}$ & $95 \% \mathrm{CI}$ & $p$-value & $\begin{array}{c}\text { Hazard } \\
\text { Ratio }\end{array}$ & $95 \% \mathrm{CI}$ & $p$-value & & & $\begin{array}{c}\text { Hazard } \\
\text { Ratio }\end{array}$ & $95 \% \mathrm{CI}$ & $p$-value & $\begin{array}{c}\text { Hazard } \\
\text { Ratio }\end{array}$ & $95 \% \mathrm{CI}$ & $p$-value \\
\hline \multirow{2}{*}{$\begin{array}{l}\text { AR related } \\
\text { signature }\end{array}$} & Group 1 & \multicolumn{3}{|c|}{ Reference } & \multicolumn{3}{|c|}{ Reference } & \multirow{2}{*}{$\begin{array}{l}\text { AR related } \\
\text { signature }\end{array}$} & Group 1 & \multicolumn{3}{|c|}{ Reference } & \multicolumn{3}{|c|}{ Reference } \\
\hline & Group 2 & 1.25 & $\begin{array}{c}1.09-1.4 \\
3\end{array}$ & $0.0013^{*}$ & 1.23 & $\begin{array}{c}1.06-1.4 \\
2\end{array}$ & $0.0066^{*}$ & & Group 2 & 1.61 & $\begin{array}{c}1.11-2.3 \\
2\end{array}$ & $0.011^{*}$ & 1.82 & $\begin{array}{c}1.08-3.0 \\
6\end{array}$ & $0.026^{*}$ \\
\hline \multirow{2}{*}{$\begin{array}{l}\text { Tumour } \\
\text { size }\end{array}$} & $<2 \mathrm{~cm}$ & \multicolumn{3}{|c|}{ Reference } & \multicolumn{3}{|c|}{ Reference } & \multirow{2}{*}{$\begin{array}{l}\text { Tumour } \\
\text { size }\end{array}$} & $\mathrm{T} 2-4$ & \multicolumn{3}{|c|}{ Reference } & \multicolumn{3}{|c|}{ Reference } \\
\hline & $\geq 2 \mathrm{~cm}$ & 1.83 & $\begin{array}{c}1.57-2.1 \\
5\end{array}$ & $<0.0001 *$ & 1.60 & $\begin{array}{c}1.36-1.8 \\
9\end{array}$ & $<0.0001 *$ & & $\mathrm{~T} 1$ & 1.67 & $\begin{array}{c}1.07-2.6 \\
2\end{array}$ & $0.026^{*}$ & 1.18 & $\begin{array}{c}0.66-2.0 \\
9\end{array}$ & 0.58 \\
\hline \multirow{2}{*}{$\begin{array}{l}\text { Nodal } \\
\text { status }\end{array}$} & Negative & \multicolumn{3}{|c|}{ Reference } & \multicolumn{3}{|c|}{ Reference } & \multirow{2}{*}{$\begin{array}{l}\text { Nodal } \\
\text { status }\end{array}$} & Negative & \multicolumn{3}{|c|}{ Reference } & \multicolumn{3}{|c|}{ Reference } \\
\hline & Positive & 1.86 & $\begin{array}{c}1.63-2.1 \\
2\end{array}$ & $<0.0001 *$ & 1.62 & $\begin{array}{c}1.40-1.8 \\
6\end{array}$ & $<0.0001 *$ & & Positive & 2.05 & $\begin{array}{c}1.38-3.0 \\
2\end{array}$ & $0.00033^{*}$ & 1.75 & $\begin{array}{c}1.05-2.9 \\
1\end{array}$ & $0.032 *$ \\
\hline Grade & Grade 3 & 1.42 & $\begin{array}{c}1.24-1.6 \\
3\end{array}$ & $<0.0001 *$ & 1.10 & $\begin{array}{c}0.94-1.2 \\
8\end{array}$ & 0.25 & Grade & Grade 3 & 1.36 & $\begin{array}{c}0.92-2.0 \\
0\end{array}$ & 0.13 & 0.93 & $\begin{array}{c}0.54-1.6 \\
0\end{array}$ & 0.78 \\
\hline & Positive & & Referenc & & & Refereno & & & Positive & & Referenc & & & Referenc & \\
\hline ER & Negative & 1.37 & $\begin{array}{c}1.18-1.5 \\
9\end{array}$ & $<0.0001 *$ & 1.08 & $\begin{array}{c}0.88-1.3 \\
2\end{array}$ & 0.46 & ER & Negative & 1.69 & $\begin{array}{c}1.13-2.5 \\
2\end{array}$ & $0.011 *$ & 1.61 & $\begin{array}{c}0.73-3.5 \\
6\end{array}$ & 0.24 \\
\hline & Positive & & Referenc & & & Refereno & & & Positive & & Referenc & & & Referenc & \\
\hline PR & Negative & 1.44 & $\begin{array}{c}1.26-1.6 \\
4\end{array}$ & $<0.0001 *$ & 1.29 & $\begin{array}{c}1.09-1.5 \\
2\end{array}$ & $0.0025^{*}$ & PR & Negative & 1.55 & $\begin{array}{c}1.06-2.2 \\
7\end{array}$ & $0.025^{*}$ & 1.18 & $\begin{array}{c}0.57-2.4 \\
7\end{array}$ & 0.66 \\
\hline & Negative & & Referenc & & & Referenc & & & Negative & & Referenc & & & Referenc & \\
\hline HER2 & Positive & 1.57 & $\begin{array}{c}1.31-1.8 \\
9\end{array}$ & $<0.0001 *$ & 1.27 & $\begin{array}{c}1.04-1.5 \\
6\end{array}$ & $0.022 *$ & HER2 & Positive & 1.57 & $\begin{array}{c}0.95-2.5 \\
9\end{array}$ & 0.076 & 1.24 & $\begin{array}{c}0.70-2.2 \\
0\end{array}$ & 0.46 \\
\hline $\begin{array}{l}\text { Dbreviati } \\
\text { Significa }\end{array}$ & R: oes & $\mathrm{rec}$ & ; PR: p & terone & pr; & nfiden & erva & & rmal gro & & & : andro & ptor. & & \\
\hline
\end{tabular}


Table 3. Survival analysis based on clinicopathological characteristics of breast cancer, including ANK3 expression in tumours with high AR expression group.

\begin{tabular}{|c|c|c|c|c|c|c|c|}
\hline \multirow{2}{*}{\multicolumn{2}{|c|}{ Factors }} & \multicolumn{3}{|c|}{ Univariate analysis } & \multicolumn{3}{|c|}{ Multivariate analysis } \\
\hline & & Hazard Ratio & $95 \% \mathrm{CI}$ & $p$-value & Hazard Ratio & $95 \% \mathrm{CI}$ & $p$-value \\
\hline \multirow{2}{*}{ ANK3 expression } & High & \multicolumn{3}{|c|}{ Reference } & \multicolumn{3}{|c|}{ Reference } \\
\hline & Low & 1.49 & $1.07-2.09$ & $0.020 *$ & 1.47 & $1.05-2.07$ & $0.025^{*}$ \\
\hline \multirow{2}{*}{ Tumour size } & $<2 \mathrm{~cm}$ & \multicolumn{3}{|c|}{ Reference } & \multicolumn{3}{|c|}{ Reference } \\
\hline & $\geq 2 \mathrm{~cm}$ & 2.61 & $1.86-3.69$ & $<0.0001 *$ & 1.75 & $1.22-2.51$ & $0.0024 *$ \\
\hline \multirow{2}{*}{ Nodal status } & Negative & \multicolumn{3}{|c|}{ Reference } & \multicolumn{3}{|c|}{ Reference } \\
\hline & Positive & 2.84 & $2.05-3.92$ & $<0.0001 *$ & 2.22 & $1.58-3.11$ & $<0.0001 *$ \\
\hline \multirow{2}{*}{ Histological grade } & Grades 1 and 2 & \multicolumn{3}{|c|}{ Reference } & \multicolumn{3}{|c|}{ Reference } \\
\hline & Grade 3 & 3.27 & $2.36-4.53$ & $<0.0001^{*}$ & 2.23 & $1.57-3.16$ & $<0.0001^{*}$ \\
\hline \multirow{3}{*}{ Subtypes } & HR-positive/HER2-negative & \multicolumn{3}{|c|}{ Reference } & \multicolumn{3}{|c|}{ Reference } \\
\hline & HER2-positive & 3.49 & $2.40-5.08$ & $<0.0001^{*}$ & 2.31 & $1.55-3.44$ & $<0.0001 *$ \\
\hline & Triple negative & 1.6 & $0.83-3.05$ & 0.16 & 1.27 & $0.65-2.47$ & 0.49 \\
\hline
\end{tabular}

Abbreviations: ANK3: ankyrin 3; AR: androgen receptor; CI: confidence interval; HER2: human epidermal growth factor receptor 2; HR: hormone receptor. *Significant difference, $p<0.05$. 
a)

Group 1

Group 2

Low

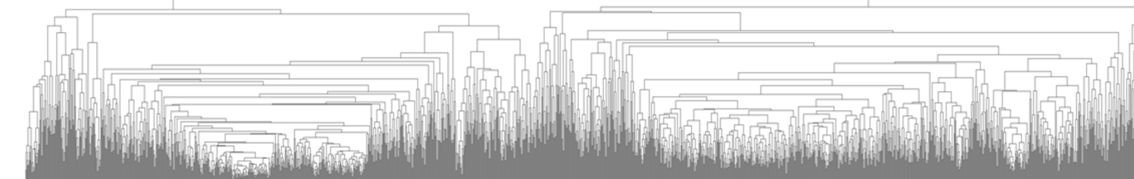

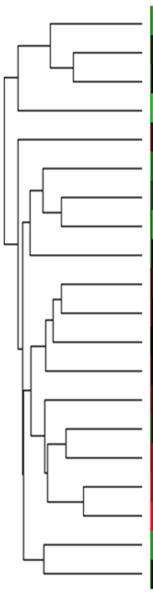

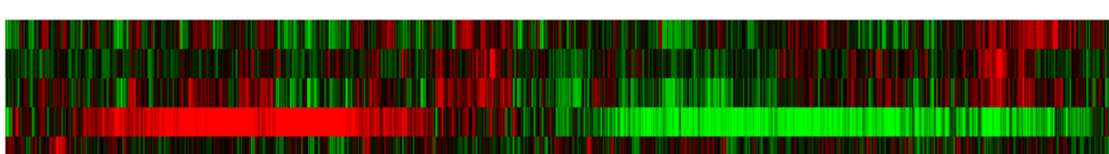

b)

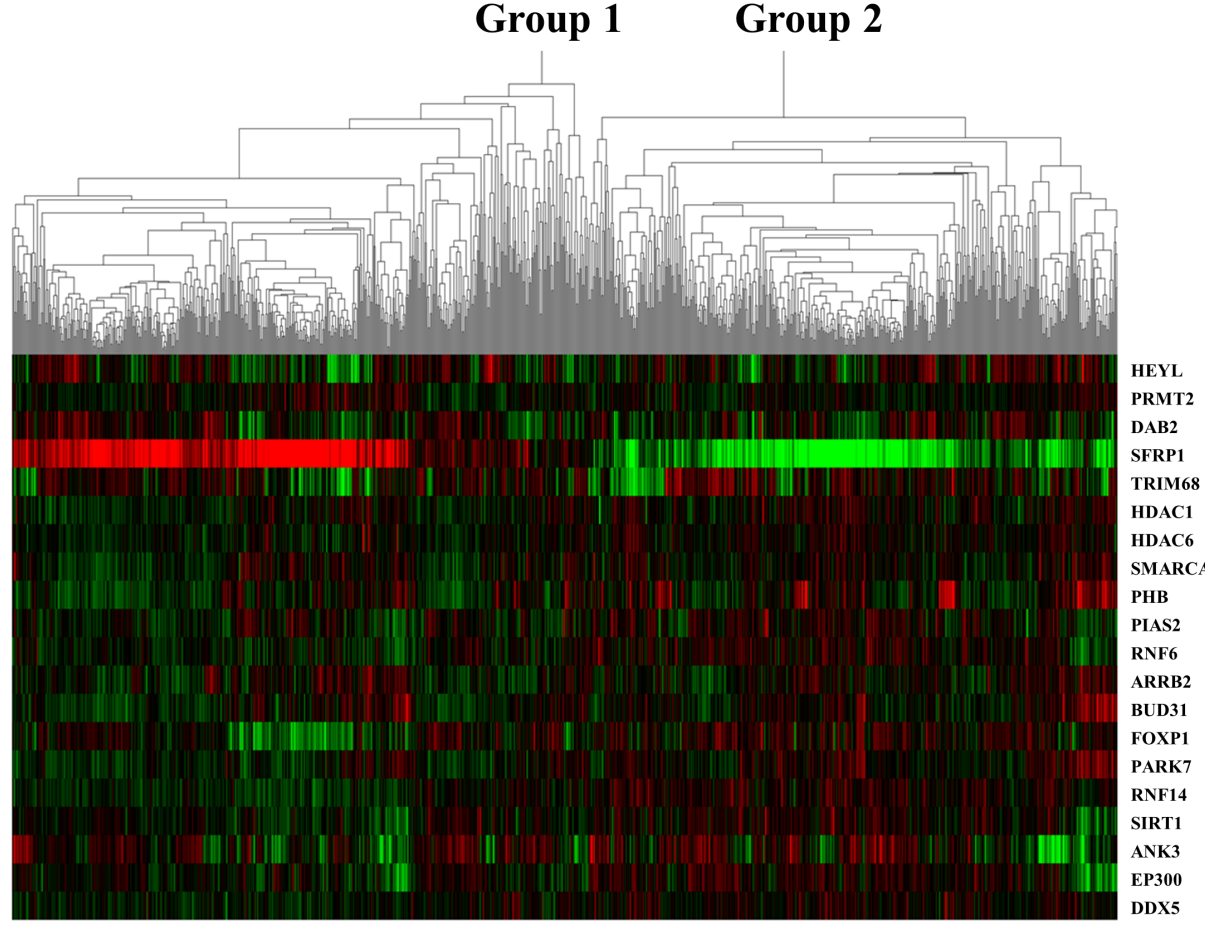

c)

Genes signature associated with AR signalng pathway with ANK 3

Figure 1
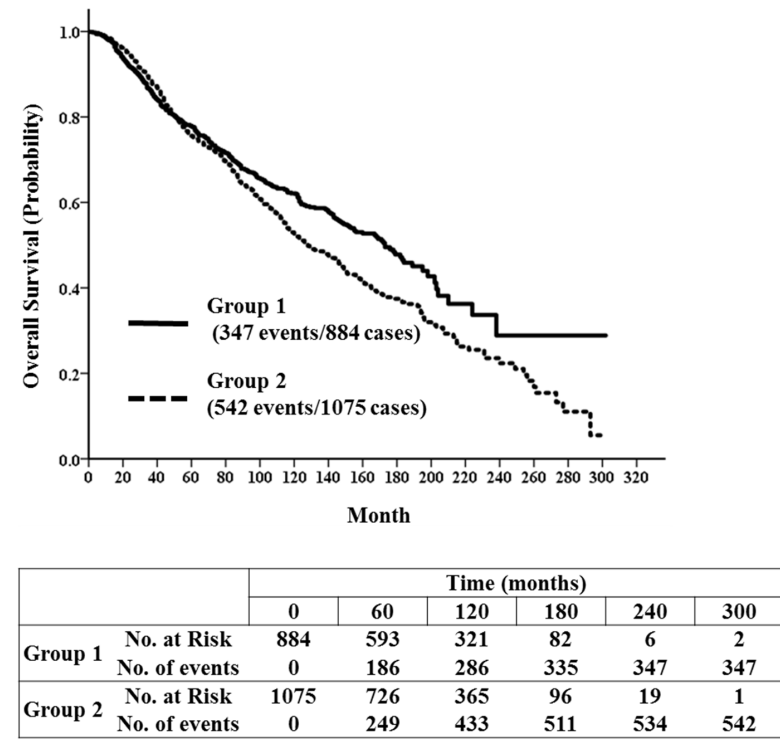

d)

Genes signature associated with AR signalng pathway with ANK3 Group 1 vs. Group 2: Hazard Ratio: 1.61,95\% CI: 1.11-2.32, $p=0.011$

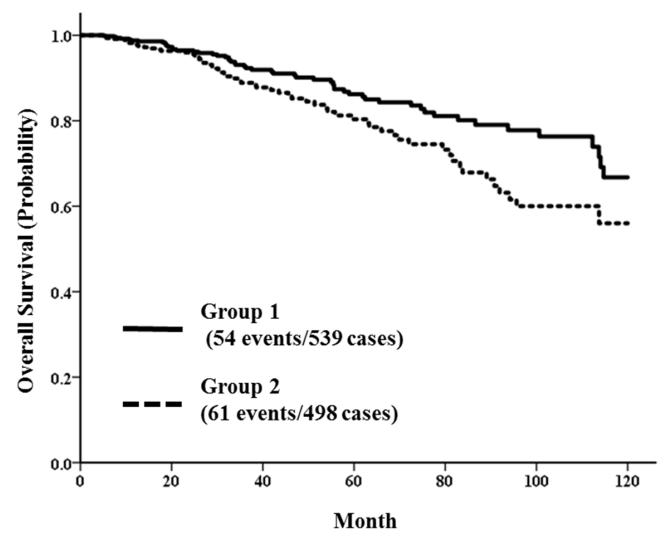

\begin{tabular}{|c|c|c|c|c|c|c|c|}
\hline & \multicolumn{8}{|c|}{ Time (months) } \\
\cline { 2 - 8 } & $\mathbf{0}$ & $\mathbf{2 0}$ & $\mathbf{4 0}$ & $\mathbf{6 0}$ & $\mathbf{8 0}$ & $\mathbf{1 0 0}$ & $\mathbf{1 2 0}$ \\
\hline Group 1 No. at Risk & $\mathbf{5 3 9}$ & $\mathbf{3 6 5}$ & $\mathbf{2 1 6}$ & $\mathbf{1 4 7}$ & $\mathbf{8 9}$ & $\mathbf{5 3}$ & 23 \\
No. of events & $\mathbf{0}$ & $\mathbf{1 2}$ & $\mathbf{2 8}$ & 39 & 46 & $\mathbf{4 9}$ & 54 \\
\hline Group 2 No. at Risk & $\mathbf{4 9 8}$ & $\mathbf{2 8 8}$ & $\mathbf{1 5 4}$ & $\mathbf{9 1}$ & $\mathbf{5 6}$ & $\mathbf{2 7}$ & $\mathbf{1 3}$ \\
No. of events & $\mathbf{0}$ & $\mathbf{1 5}$ & $\mathbf{3 4}$ & $\mathbf{4 4}$ & $\mathbf{5 1}$ & $\mathbf{6 0}$ & $\mathbf{6 1}$ \\
\hline
\end{tabular}




\section{Figure 2}

a)

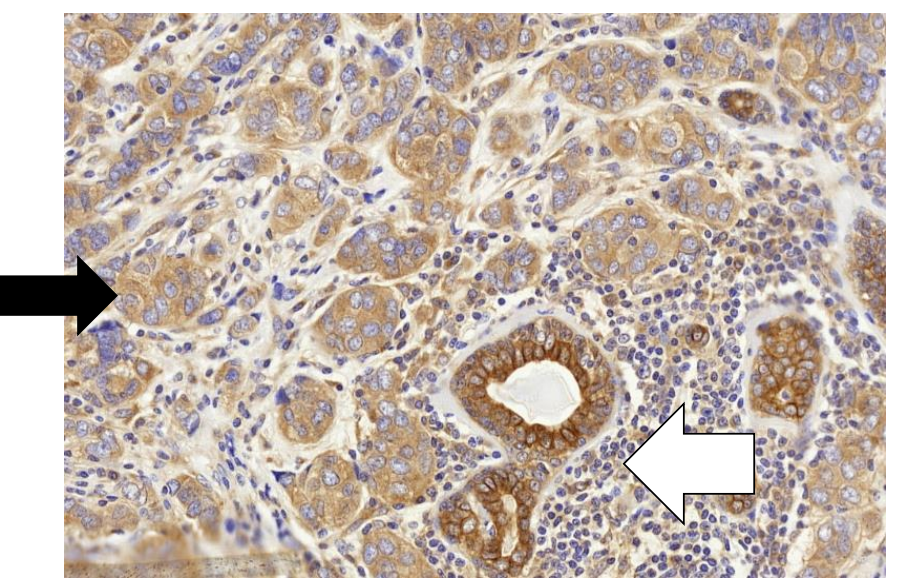

b)

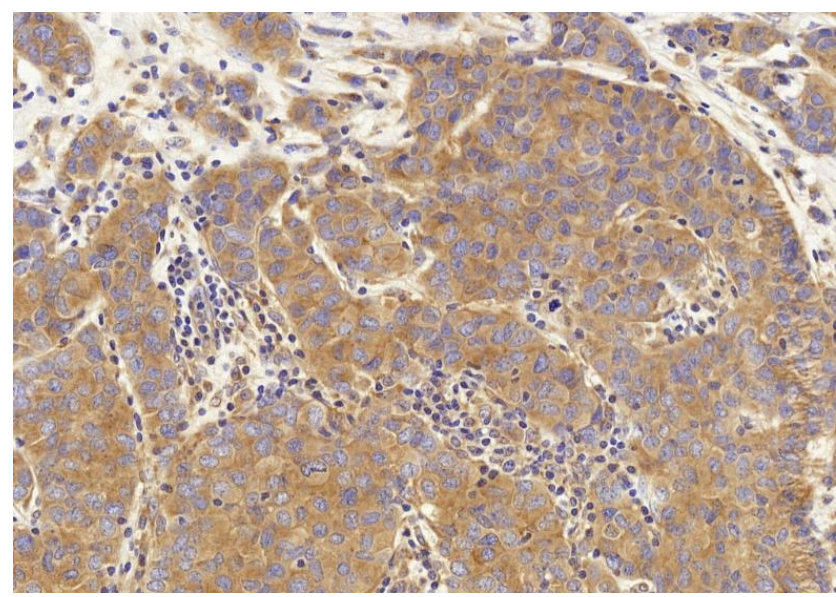

c)

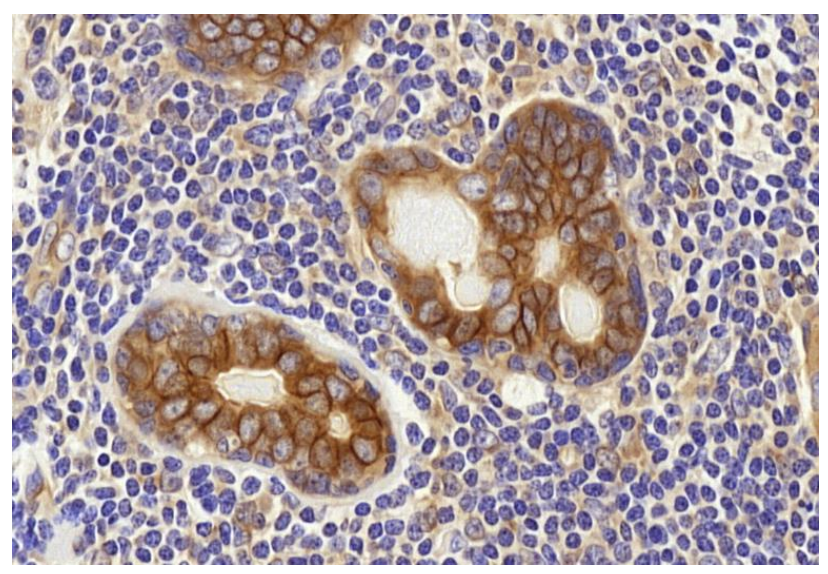

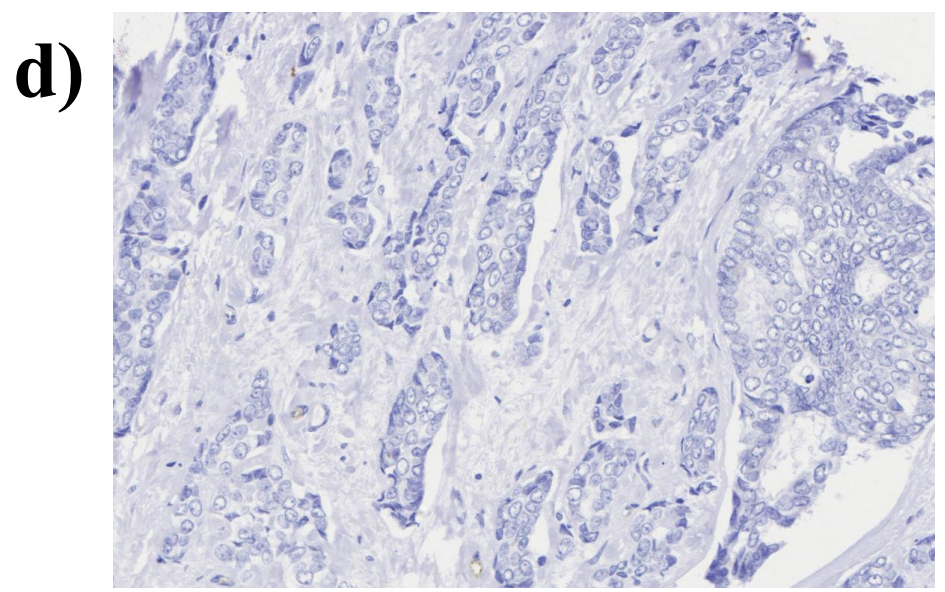

e)

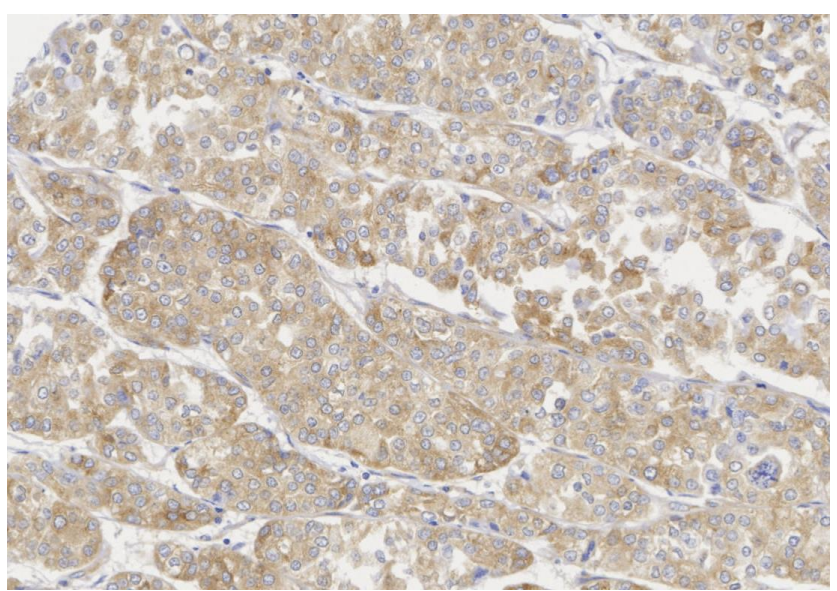

f)

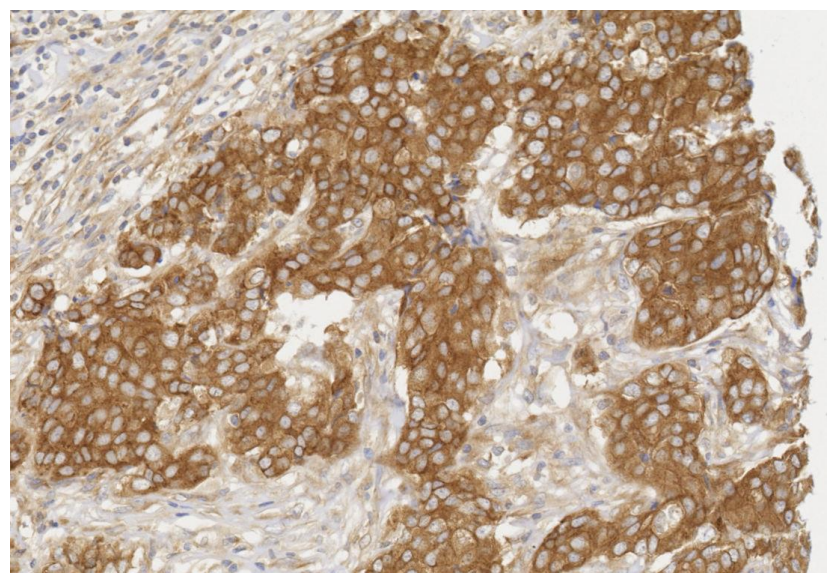


a)

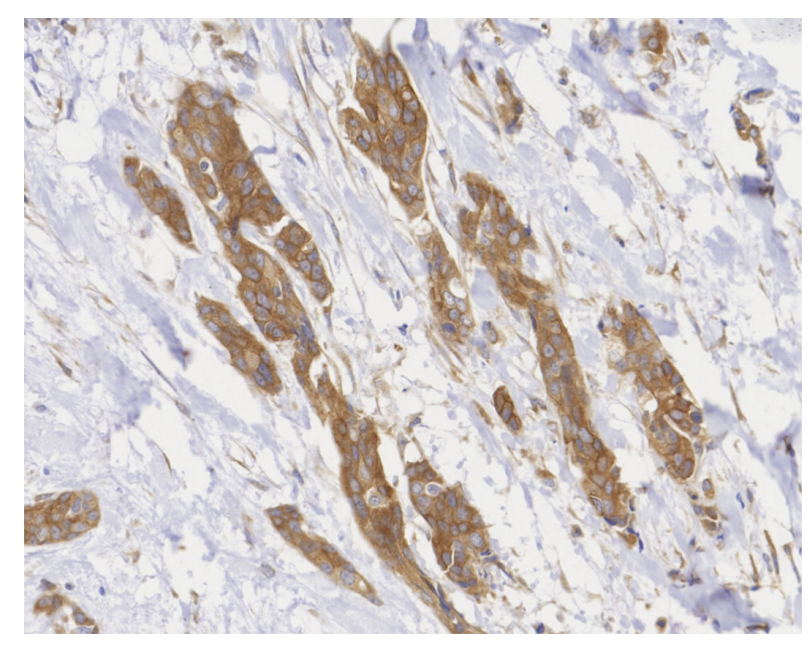

b)

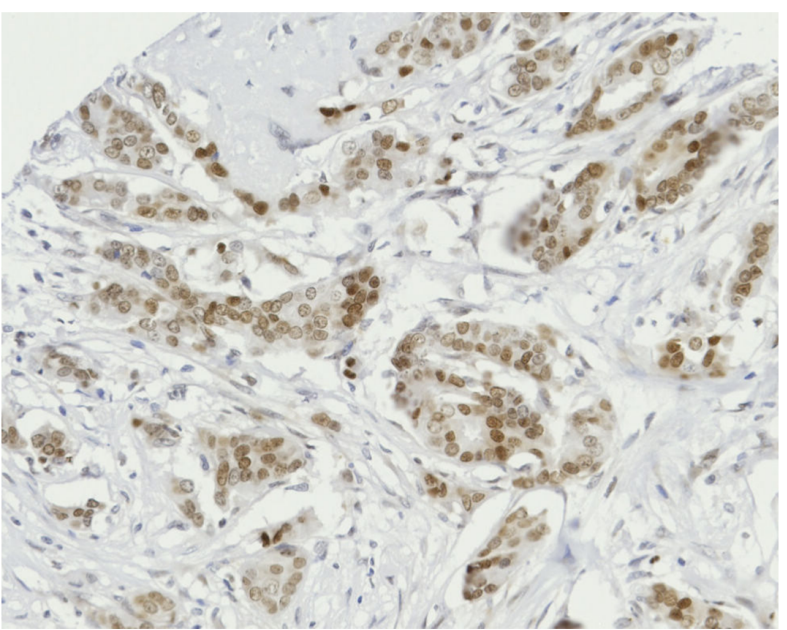

c)

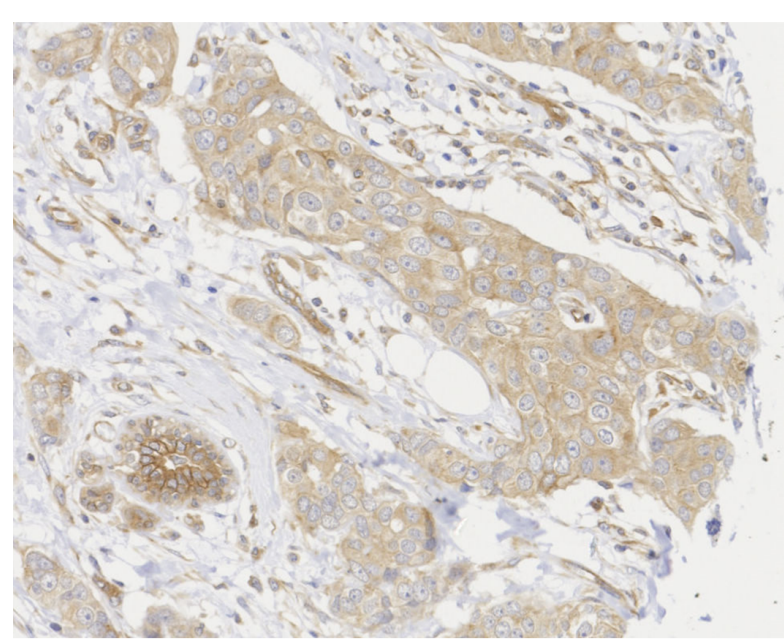

d)

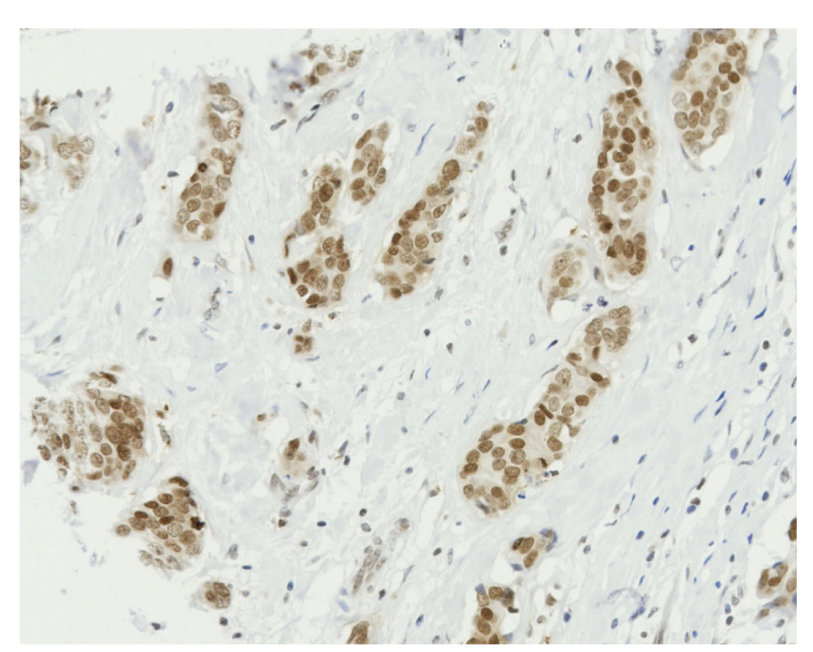

e)

High AR expression cases

High vs. low ANK3 protein expression Hazard ratio $1.49,95 \%$ CI: 1.07-2.09, $p=0.020$

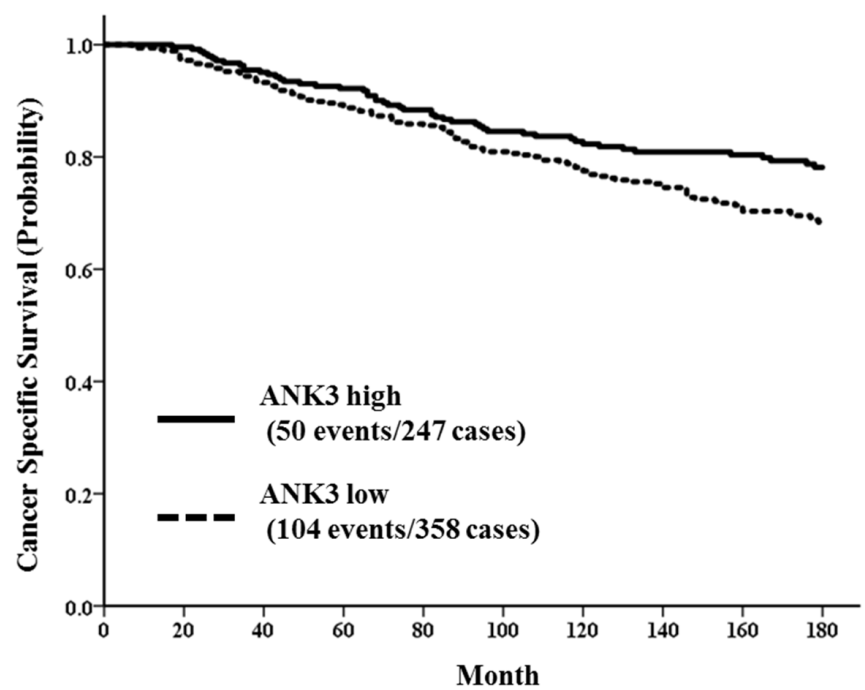

\begin{tabular}{|c|c|c|c|c|c|c|c|}
\hline \multirow{2}{*}{\multicolumn{2}{|c|}{ ANK3 }} & \multicolumn{6}{|c|}{ Time (months) } \\
\hline & & 0 & 30 & 60 & 90 & 120 & 180 \\
\hline \multirow{2}{*}{ Low } & No. at Risk & 358 & 339 & 313 & 284 & 243 & 172 \\
\hline & No. of events & 0 & 17 & 39 & 61 & 78 & 104 \\
\hline \multirow{2}{*}{ High } & No. at Risk & 247 & 235 & 219 & 203 & 181 & 131 \\
\hline & No. of events & 0 & 8 & 19 & 33 & 42 & 50 \\
\hline
\end{tabular}

\section{Figure 3}


Supplementary Table 1. Patients' characteristics of high and low androgen receptor expression groups in the Nottingham primary cohort

\begin{tabular}{|c|c|c|c|c|}
\hline \multirow{2}{*}{\multicolumn{2}{|c|}{ Factors }} & \multicolumn{2}{|c|}{ Expression of AR } & \multirow{2}{*}{$p$-value } \\
\hline & & \multirow{2}{*}{$\frac{\text { High group }}{\text { 24-70 (median: } 54)}$} & \multirow{2}{*}{$\begin{array}{c}\text { Low group } \\
\text { 25-70 (median: } 51.5)\end{array}$} & \\
\hline \multirow{3}{*}{ ANK3 } & Age range in year & & & $<0.0001 *$ \\
\hline & High & $250(62.0 \%)$ & $153(38.0 \%)$ & 70 \\
\hline & Low & $364(62.9 \%)$ & $215(37.1 \%)$ & 0.19 \\
\hline \multirow{2}{*}{ Menopausal status } & Pre- & $236(58.0 \%)$ & $171(42.0 \%)$ & \multirow{2}{*}{$0.013^{*}$} \\
\hline & Post- & $378(65.7 \%)$ & $197(34.3 \%)$ & \\
\hline \multirow{2}{*}{ Tumour size } & $\geq 2 \mathrm{~cm}$ & $313(58.8 \%)$ & $219(41.2 \%)$ & \multirow{2}{*}{$0.0094 *$} \\
\hline & $<2 \mathrm{~cm}$ & $301(66.9 \%)$ & $149(33.1 \%)$ & \\
\hline \multirow{2}{*}{ Nodal status } & Positive & $239(62.6 \%)$ & $143(37.4 \%)$ & \multirow{2}{*}{0.98} \\
\hline & Negative & $375(62.5 \%)$ & $225(37.5 \%)$ & \\
\hline \multirow{2}{*}{ Histological grade } & Grade 3 & $232(46.1 \%)$ & $271(53.9 \%)$ & \multirow{2}{*}{$<0.0001 *$} \\
\hline & Grade 1 and 2 & $382(79.7 \%)$ & $97(20.3 \%)$ & \\
\hline \multirow{3}{*}{ Subtypes } & HR-positive/HER2-negative & $510(76.7 \%)$ & $155(23.3 \%)$ & \multirow{3}{*}{$<0.0001^{*}$} \\
\hline & HER2-positive & $72(56.7 \%)$ & $55(43.3 \%)$ & \\
\hline & Triple negative & $32(16.8 \%)$ & $158(83.2 \%)$ & \\
\hline \multirow{2}{*}{ Type of breast surgery } & Breast-conserving surgery & $282(65.6 \%)$ & $148(34.4 \%)$ & \multirow{2}{*}{0.081} \\
\hline & Mastectomy & $332(60.1 \%)$ & $220(39.9 \%)$ & \\
\hline \multirow[b]{2}{*}{ Axillary surgery } & Sampling alone & $371(62.2 \%)$ & $225(37.8 \%)$ & \multirow[b]{2}{*}{0.92} \\
\hline & Axillary lymph node dissection & $239(62.6 \%)$ & $143(37.4 \%)$ & \\
\hline
\end{tabular}




\begin{tabular}{|c|c|c|c|}
\cline { 2 - 4 } & No surgery & $4(100.0 \%)$ & $0(0.0 \%)$ \\
\hline \multirow{3}{*}{ Chemotherapy } & Yes & $83(39.9 \%)$ & $125(60.1 \%)$ \\
\cline { 2 - 4 } & No & $512(69.8 \%)$ & $222(30.2 \%)$ \\
\hline \multirow{3}{*}{ Endocrine therapy } & Unknown & $19(47.5 \%)$ & $21(52.5 \%)$ \\
\cline { 2 - 4 } & Yes & $258(69.2 \%)$ & $115(30.8 \%)$ \\
\cline { 2 - 4 } & No & $337(59.2 \%)$ & $232(40.8 \%)$ \\
\hline
\end{tabular}

Abbreviations: ANK3: ankyrin 3; HER2: human epidermal growth factor receptor 2; HR: hormone receptor.

* Significant difference $\mathrm{p}<0.05$. 
Supplementary Table 2. List of genes in the gene signature associated with AR signaling pathway

\begin{tabular}{|c|c|}
\hline Gene symbol & Gene name \\
\hline ANK3 & Ankyrin 3 \\
\hline ARRB2 & Arrestin Beta 2 \\
\hline BUD31 & BUD31 Homolog \\
\hline DAB2 & DAB2, Clathrin Adaptor Protein \\
\hline DDX5 & DEAD-Box Helicase 5 \\
\hline EP300 & E1A Binding Protein P300 \\
\hline FOXP1 & Forkhead Box P1 \\
\hline HDAC1 & Histone Deacetylase 1 \\
\hline HDAC6 & Histone Deacetylase 6 \\
\hline HEYL & Hes Related Family BHLH Transcription Factor With YRPW Motif-Like \\
\hline PARK7 & Parkinsonism Associated Deglycase \\
\hline PHB & Prohibitin \\
\hline PIAS2 & Protein Inhibitor Of Activated STAT 2 \\
\hline PRMT2 & Protein Arginine Methyltransferase 2 \\
\hline RNF14 & Ring Finger Protein 14 \\
\hline RNF6 & Ring Finger Protein 6 \\
\hline SFRP1 & Secreted Frizzled Related Protein 1 \\
\hline SIRT1 & Sirtuin 1 \\
\hline SMARCA4 & SWI/SNF Related, Matrix Associated, Actin Dependent Regulator Of Chromatin, Subfamily A, Member 4 \\
\hline
\end{tabular}


Supplementary Table 3. Correlation between ANK3 expression and clinicopathological characteristics of breast cancer stratified by AR expression.

\begin{tabular}{|c|c|c|c|c|c|c|c|}
\hline & \multirow{3}{*}{ Factors } & \multicolumn{3}{|c|}{ High AR group } & \multicolumn{3}{|c|}{ Low AR group } \\
\hline & & \multicolumn{2}{|c|}{ Expression of ANK3 } & \multirow{2}{*}{$p$-value } & \multicolumn{2}{|c|}{ Expression of ANK3 } & \multirow{2}{*}{$p$-value } \\
\hline & & High & Low & & High & Low & \\
\hline \multirow{2}{*}{ Tumour size } & $\geq 2 \mathrm{~cm}$ & $120(38.3 \%)$ & $193(61.7 \%)$ & \multirow{2}{*}{0.22} & $95(43.4 \%)$ & $124(56.6 \%)$ & \multirow{2}{*}{0.40} \\
\hline & $<2 \mathrm{~cm}$ & $130(43.2 \%)$ & $171(56.8 \%)$ & & $58(38.9 \%)$ & $91(61.1 \%)$ & \\
\hline \multirow{2}{*}{ Nodal status } & Positive & $95(39.7 \%)$ & $144(60.3 \%)$ & \multirow{2}{*}{0.70} & $62(43.4 \%)$ & $81(56.6 \%)$ & \multirow{2}{*}{0.58} \\
\hline & Negative & $155(41.3 \%)$ & $220(58.7 \%)$ & & $91(40.4 \%)$ & $134(59.6 \%)$ & \\
\hline \multirow{2}{*}{ Histological grade } & Grade 3 & $96(41.4 \%)$ & $136(58.6 \%)$ & \multirow{2}{*}{0.80} & $119(43.9 \%)$ & $152(56.1 \%)$ & \multirow{2}{*}{0.13} \\
\hline & Grades 1 and 2 & $154(40.3 \%)$ & $228(59.7 \%)$ & & $34(35.1 \%)$ & $63(64.9 \%)$ & \\
\hline \multirow{2}{*}{ ER } & Positive & $225(40.8 \%)$ & $326(59.2 \%)$ & \multirow{2}{*}{0.86} & $64(36.4 \%)$ & $112(63.6 \%)$ & \multirow{2}{*}{0.052} \\
\hline & Negative & $25(39.7 \%)$ & $38(60.3 \%)$ & & $89(46.4 \%)$ & $103(53.6 \%)$ & \\
\hline PR & Negative & $55(32.7 \%)$ & $113(67.3 \%)$ & $0.014 *$ & $102(43.0 \%)$ & $135(57.0 \%)$ & 0.44 \\
\hline \multirow{2}{*}{ HER2 } & Positive & $29(40.3 \%)$ & $43(59.7 \%)$ & \multirow{2}{*}{0.94} & $25(45.5 \%)$ & $30(54.5 \%)$ & \multirow{2}{*}{0.53} \\
\hline & Negative & $221(40.8 \%)$ & $321(59.2 \%)$ & & $128(40.9 \%)$ & $185(59.1 \%)$ & \\
\hline \multirow{3}{*}{ Subtypes } & HR-positive/HER2-negative & $208(40.8 \%)$ & $302(59.2 \%)$ & \multirow{3}{*}{1.00} & $56(36.1 \%)$ & $99(63.9 \%)$ & \multirow{3}{*}{0.20} \\
\hline & HER2-positive & $29(40.3 \%)$ & $43(59.7 \%)$ & & $25(45.5 \%)$ & $30(54.5 \%)$ & \\
\hline & Triple negative & $13(40.6 \%)$ & $19(59.4 \%)$ & & $72(45.6 \%)$ & $86(54.4 \%)$ & \\
\hline \multirow{2}{*}{$\mathrm{Ki} 67$} & $\operatorname{High}(\geq 10 \%)$ & $120(44.4 \%)$ & $150(55.6 \%)$ & \multirow{2}{*}{0.12} & $100(44.1 \%)$ & $127(55.9 \%)$ & \multirow{2}{*}{0.59} \\
\hline & Low $(<10 \%)$ & $85(37.6 \%)$ & $141(62.4 \%)$ & & $27(40.3 \%)$ & $40(59.7 \%)$ & \\
\hline \multicolumn{8}{|c|}{$\begin{array}{l}\text { Abbreviations: ANK3: ankyrin 3; AR: androgen receptor; ER: oestrogen receptor; PR: progesterone receptor; HR: hormone receptor. } \\
\text { Some variables have missing data. } \\
\text { *Significant difference, } p<0.05 \text {. }\end{array}$} \\
\hline
\end{tabular}


Survival analysis stratified by $A R$ mRNA expression

METABRIC cohort

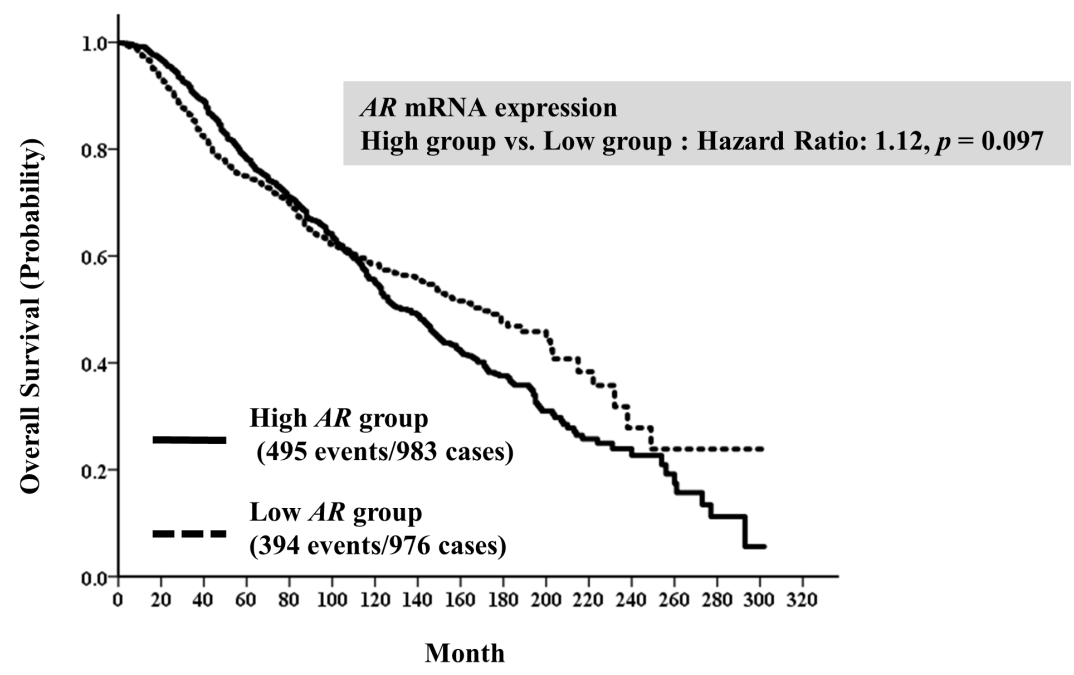

TCGA cohort

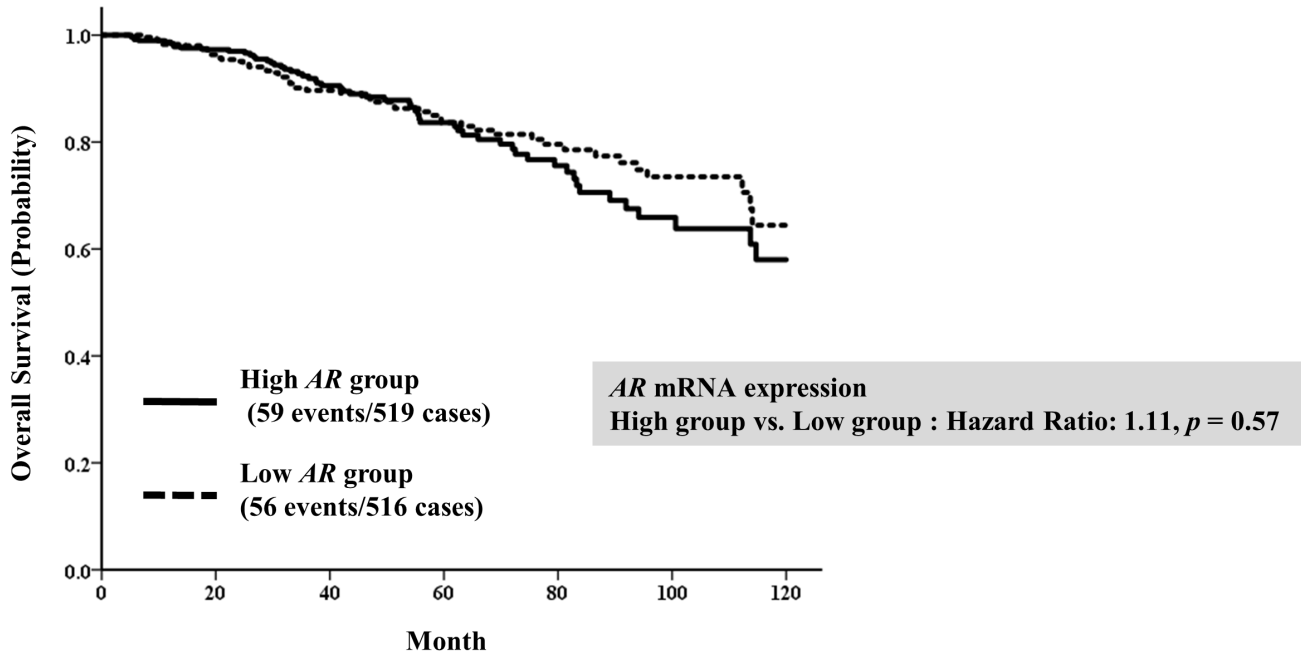

Survival analysis stratified by $A N K 3$ mRNA expression

METABRIC cohort

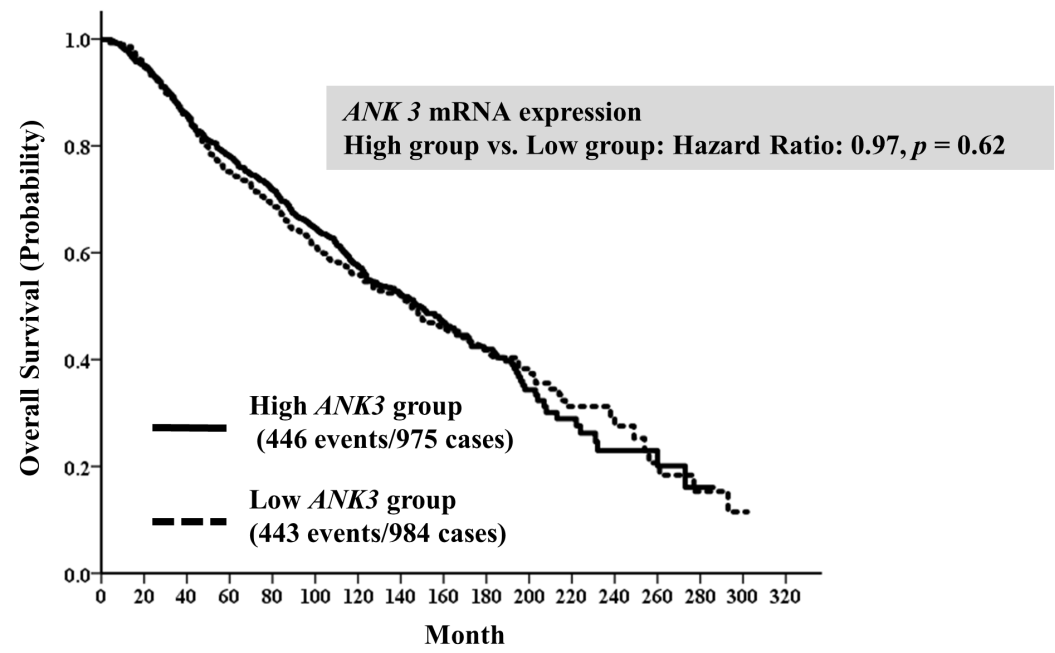

TCGA cohort

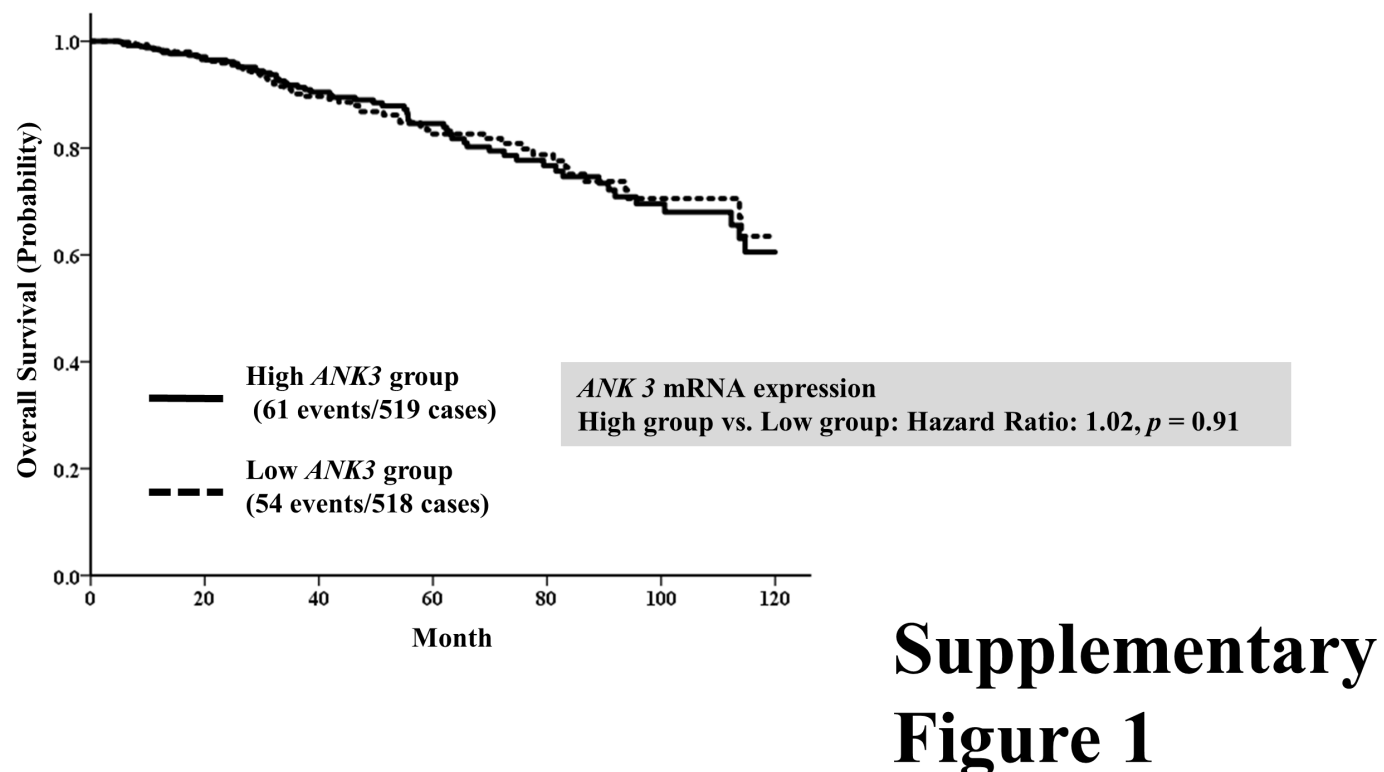




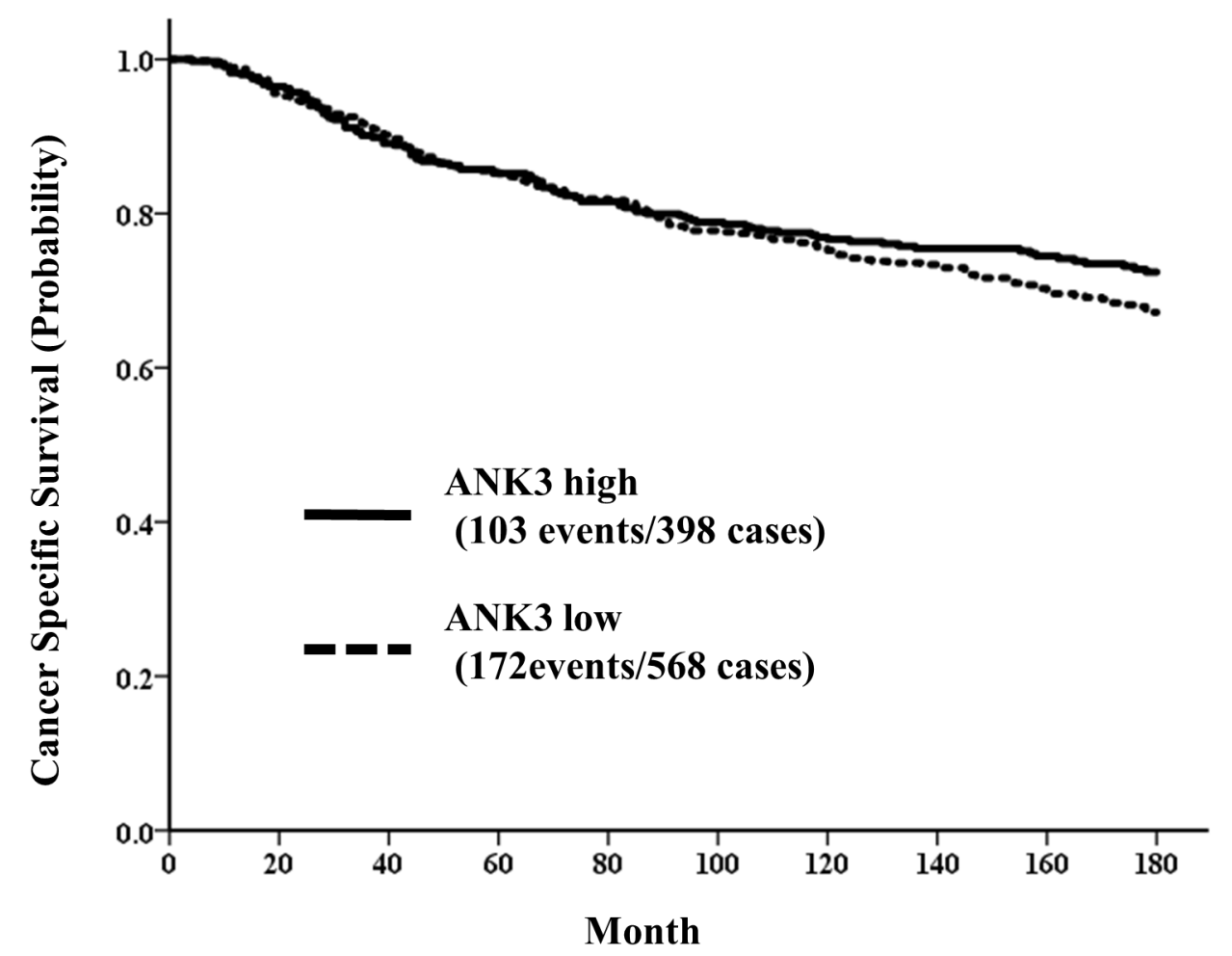

For protein expression of ANK3

High vs. Low: Hazard Ratio: 0.85, 95\% CI: 0.67-1.08, $p=0.19$

\section{Supplementary}

Figure 2 


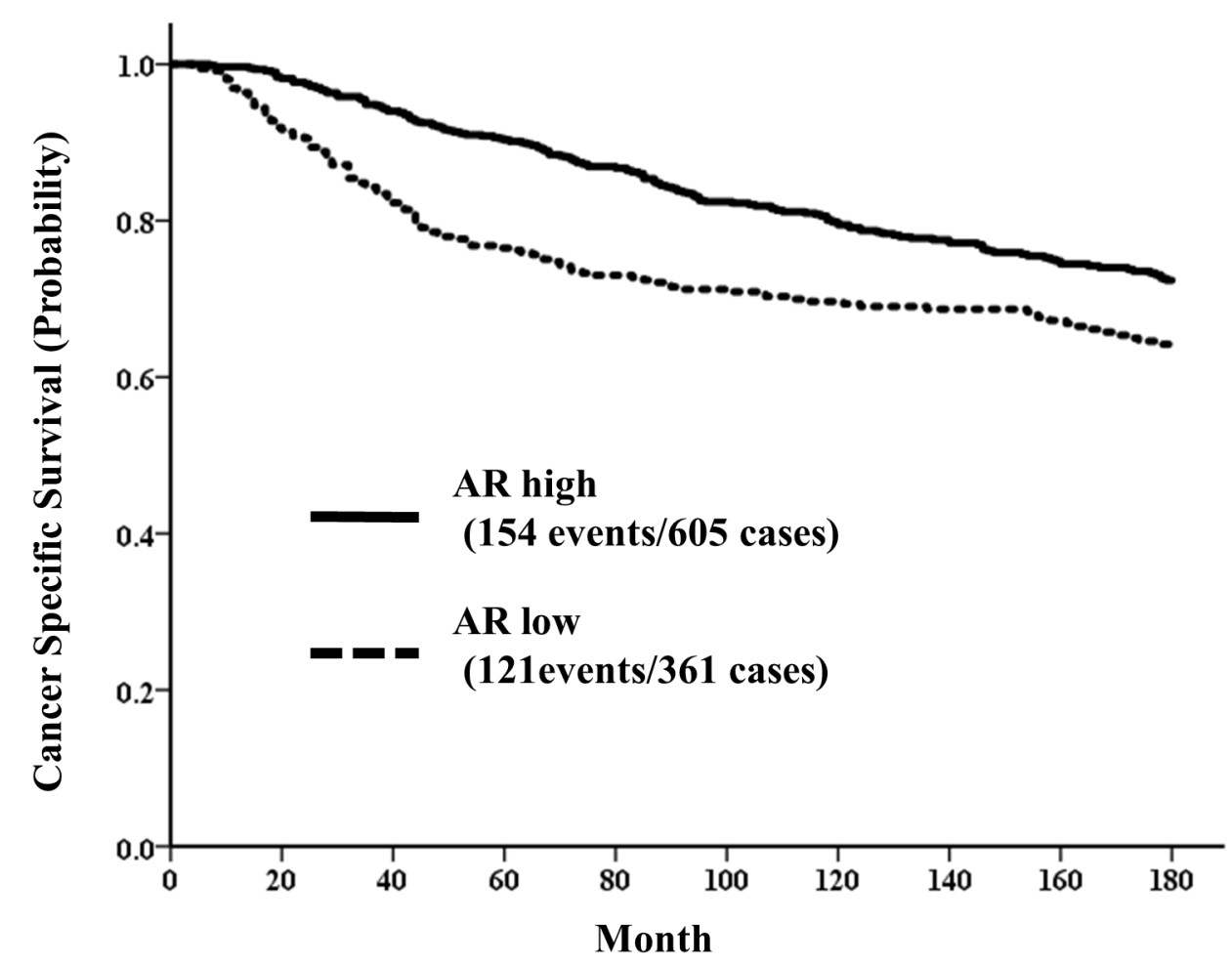

For protein expression of $A R$

High vs. Low: Hazard Ratio: 0.66, 95\% CI: 0.52-0.84

$p=0.00066$

\section{Supplementary}

Figure 3 


\section{Low AR expression cases}

High vs. low ANK3 protein expression Hazard ratio $0.89,95 \%$ CI: $0.62-1.28$, $p=0.53$

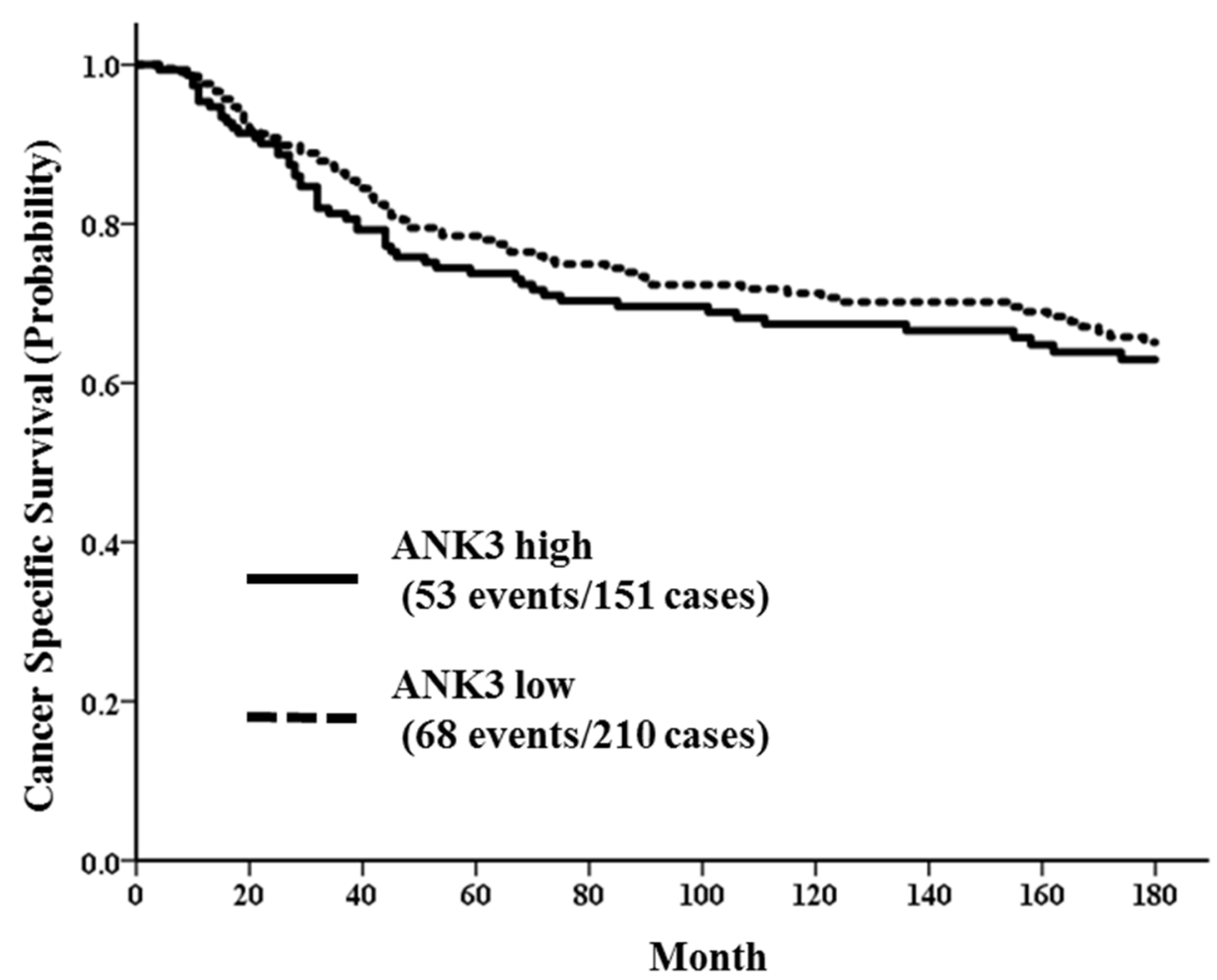

\section{Supplementary}

\begin{tabular}{|c|c|c|c|c|c|c|c|}
\hline \multirow{2}{*}{\multicolumn{2}{|c|}{ ANK3 }} & \multicolumn{6}{|c|}{ Time (months) } \\
\hline & & 0 & 30 & 60 & 90 & 120 & 180 \\
\hline \multirow{2}{*}{ Low } & No. at Risk & 210 & 181 & 157 & 140 & 132 & 94 \\
\hline & No. of events & 0 & 23 & 44 & 55 & 58 & 68 \\
\hline \multirow{2}{*}{ High } & No. at Risk & 151 & 125 & 107 & 99 & 86 & 63 \\
\hline & No. of events & 0 & 23 & 39 & 45 & 48 & 53 \\
\hline
\end{tabular}

Figure 4 